\title{
Institutionalized Bailouts and Fiscal Policy: The Consequences of Soft Budget Constraints
}

\author{
Alexander Fink \\ Thomas Stratmann
}

CESIFO WORKING PAPER No. 2827

CATEgory 1: Public Finance

OCTOBER 2009

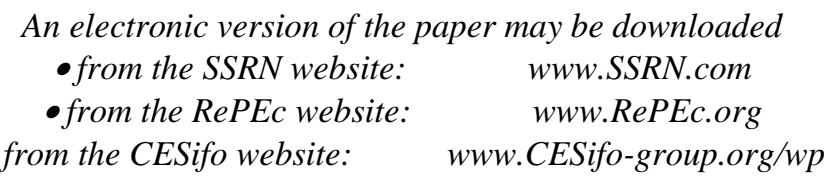




\title{
Institutionalized Bailouts and Fiscal Policy: The Consequences of Soft Budget Constraints
}

\begin{abstract}
States have soft budget constraints when they can expect a bailout by the federal government in the event of a financial crisis. This gives rise to incentives for unsound state fiscal policy. We test whether states with softer budget constraints have higher debt and deficits, receive more bailouts funds, spend funds less efficiently, and are more likely to allocate funds to programs benefiting special interests. Exogenous variation in soft budget constraints across states and over time allows the identification of budget constraint softness on state fiscal policy. We take advantage of the fact that in Germany, states' political influence is exogenous because voting weights differ in the upper chamber of the German parliament. The stronger the political influence of states, the softer their budget constraints. We show that states with softer budget constraint have higher deficits and debts, and receive more bailouts funds. Further, overrepresented states are less efficient in spending public funds and are more prone to respond to rent seeking by interest groups.
\end{abstract}

JEL Code: H70, H11, E62, E63.

Alexander Fink

Department of Economics

George Mason University

afink2@gmu.edu
Thomas Stratmann

Department of Economics

George Mason University

tstratma@gmu.edu

October 2009

We would like to thank Thiess Büttner for helpful comments and suggestions. 


\section{Introduction}

In many countries state governments face soft budget constraints. Budget constraints are soft when state governments can expect to be bailed out by the federal government in times of financial crisis (Kornai 1979, 1986, 1998, Kornai, Maskin and Roland 2003). State government officials have a bailout expectation because the federal government is unable to credibly commit ex ante to a no-bailout strategy (Dewatripont and Maskin 1995). Consequently, state governments facing soft budget constraints have a weak incentive to conduct fiscally responsible policies. $^{3}$

Although the federal government could potentially bail any state government, budget constraints may not be equally soft across states. A simple political economy model predicts that politically influential states--states with more bargaining power--will take advantage of their influence over the federal government by running higher deficits, and not pursuing fiscally responsible policies. Because of their superior bargaining power, they expect to receive bailouts from the federal government in times of financial crises. When the degree of states' bailout expectations is plausibly exogenous, an empirical model can identify the effect of soft budget constraints on fiscal outcomes.

In Germany some states are politically more influential than others because states’ voting weights differ in the upper chamber of the German parliament, the Bundesrat. Less populous German states are overrepresented relative to their population size in the Bundesrat; similarly, as less populous states in the U.S. are overrepresented in the U.S. Senate. Overrepresented states have softer budget constraints and thus more bargaining power to obtain bailouts compared to states that are underrepresented in the Bundesrat. The malapportionment in the Bundesrat

\footnotetext{
${ }^{3}$ For a recent analysis of fiscal incentives on policy decisions see Weingast (2009).
} 
provides exogenous variation in bailout expectations and thus the softness of states' budget constraints. $^{4}$

In this paper we test whether states with softer budget constraints have weaker fiscal incentives, measured as higher deficits and debts. We also test whether these states receive more routine bailout funds, where we refer to bailouts as both discretionary grants from the federal government and grants that arise from the institutionalized redistribution of funds across states. Both of these institutionalized bailouts grants are in part a function of fiscal condition of states. ${ }^{5}$ We probe further into the consequences of soft budget constraints and examine whether they lead to less efficient state spending and whether softer constraints make state governments more receptive to rent seeking by special interests groups, measured as spending benefitting these groups. To estimate these effects we exploit the exogenous variation in state political power in Germany over time, and use an estimation strategy that holds state attributes, which may be correlated with soft budget constraints, constant.

Related to our study is the work on fiscal intergovernmental relations, which focuses on the federal government's problem with credibly committing ex ante to a no-bailout strategy, and the subsequent incentive effects for lower levels of government (Rodden 2002, 2003, 2006a; Wildasin 1997). ${ }^{6}$ These studies focus on identifying instances of soft budget constraints and describe how country-specific institutional structures give rise to soft budget constraints. Less

\footnotetext{
${ }^{4}$ Atlas et al. (1995) finds that overrepresentation of less populous states in the U.S. Senate led to a significantly higher amount of net federal spending per capita in these states. More recent work is consistent with this finding (see, for example, Lee 1998; Hoover and Pecorino 2005; Knight 2005; Hauk and Wacziarg 2007). While U.S. Senators vote directly on projects, and thereby determine the regional distribution of federal funds, in Germany the distribution of transfers is mostly based on formula. For Germany, Pitlik, Schmid, and Strotmann (2001) and Pitlik, Schneider, and Strotmann (2006) find that overrepresented states receive more funds.

${ }^{5}$ In part our language of referring to bailouts is motivated by Rodden (2006b, p. 142) who argues that "the model suggests that manifestations of bailout expectations among subnational governments are not limited to dramatic defaults or last minute bailouts under pressure from creditors, but in many plausible scenarios imply more routine early bailouts (gap-filling intergovernmental transfers) or delayed adjustment."

${ }^{6}$ Vigneault (2007) provides an overview of empirical investigations of soft budget constraints in the context of intergovernmental relations. For the effect of soft budget constraint in Germany on pro-cyclical fiscal policies see Stehn and Fedelino (2009).
} 
emphasis is placed on exploiting variations in the softness of the budget constraint and testing predictions about fiscal policies when states face bailout guarantees (Rodden 2002, 2003, 2006a; Wildasin 1997). ${ }^{7}$

We also investigate the consequences of other differences in states' bargaining power arising from the political similarity between the federal government and the state governments (Grossman 1994). In a model where the federal government, in order to pass legislation, has to purchase the votes of the majority of states, a state with the same political makeup as the federal government has a lower supply price of votes, and a state with the opposite political makeup has a higher supply price. But the federal government does not have to purchase votes from the latter, who have the highest supply price, because passage of legislation requires not unanimity, but only a majority of votes. Thus, states with the median supply price receive the highest price. These states tend to be both those governed by parties represented in the federal government's governing coalition, as well those not in the governing coalition. Thus, this bargaining model predicts the largest redistribution to states that have a median supply price of votes (Denzau and Munger 1986; Stratmann 1992).

We analyze annual data by state from 1970 to 2004 and find that states with softer budget constraints have higher deficits and debts, resulting from higher expenditures. Further, these states receive more bailouts funds from other states and from the federal government. We also find that states with softer budget constraints tend to spend a larger share of funds on programs benefitting special interests and also spend their funds less efficiently.

\footnotetext{
${ }^{7}$ Similar as in this study, Rodden (2006a) includes German Bundesrat seats per capita in regressions examining deficits and expenditures. However, Rodden (2006a) examines data from 1974 to 1995 for the old German states. This short time period is associated with little variation in the number of seats per capita, which prevents Rodden from including state fixed effects in the regressions. State fixed effects would control for state heterogeneity which may be correlated with seats per capita.
} 


\section{Institutions}

\section{II.A. Malapportionment in the Bundesrat}

In many federal systems the upper chamber represents the states. The number of seats allocated to a state in the upper chamber is malapportioned when the share of seats apportioned to that state does not equal the state's share of the country’s population. In the U.S., for example, two Senators represent each state even though states differ greatly in population size. Consequently, relatively unpopulated states are overrepresented in the U.S. Senate. Disproportional representation in the upper chamber is a common phenomenon and is present in more than 70 countries worldwide (Samuels and Snyder 2001).

Overrepresentation of smaller states exists also in the German Bundesrat. Although the representation in the Bundesrat is related to a state’s population, state representation is not proportional to state population. Table 1 shows that in 2004, 69 representatives in the Bundesrat represented 16 states, and each state held between three and six seats, each seat counting for one vote. The table shows that the number of seats per state was not proportional to a state's population. For example, in 2004 the state Bremen had a population of about 0.66 million and held three seats in the Bundesrat, while the state North Rhine-Westphalia has a population of approximately 18 million and held six seats in the upper chamber. Another example is the state of Thuringia which had three times as many votes per capita as Bavaria.

This malapportionment can be traced back to the founding of the Federal Republic of Germany after World War II. In 1949 the parliamentary council (Parlamentarischer Rat) drafted the German constitution (Grundgesetz). The council consisted of representatives from the German states. At that time the council decreed that each state receives at least three seats, states with a population of greater than two million receive four seats, and states with a population of 
greater than six million receive five seats (Kröger 1989). The proposed constitution, which included this allocation of seats, was ratified by the state governments. ${ }^{8}$ The advantage that small states received through this allocation of seats cannot be explained through an overrepresentation of these states in the parliamentary council. For example, the small states Bremen and Hamburg had one and two representatives respectively, whereas the large state Bavaria had 13 representatives on the council. ${ }^{9}$ Further, the small state of Saarland was not represented since it was part of France in 1949.

Between 1949 and 1990 the distribution of seats only changed when states joined the German Republic or were dissolved. However, the formula for the allocation did not change until 1990 when the eastern states joined the Bundesrat. At that time the formula changed in only one respect, namely that from 1990 onwards, states with a population of seven million or greater received six instead of five seats in the Bundesrat.

The fact that smaller states were not overrepresented in the parliamentary council which decided on the allocation of seats suggests that the seat allocation was not driven by a more than proportional political influence of small states. Further, some states had no voice in the determination of the allocation. Those states included the Saarland, Berlin, and the five eastern states which joined with the seat allocation rules already in effect.

German voters do not directly elect state representatives for the Bundesrat. State governments appoint them instead. Delegations from each state vote as a block. In contrast, German voters elect representatives to the lower chamber (Bundestag). The number of representatives in the Bundestag originating from a particular state is close to proportional to

\footnotetext{
${ }^{8}$ The Bavarian parliament rejected the Grundgesetz but accepted it conditional on its ratification in at least two thirds of the remaining states.

${ }^{9}$ In 1949 Hamburg and Bremen had the highest and second highest per capita incomes.
} 
state population, because German electoral law mandates that the population size in each electoral district may not deviate by more than 25 percent from the population size in the average district, and because any remaining disproportionality at the state level is eliminated by adjusting the number of state party list members entering the Bundestag,

The institutional role of the Bundesrat is to accept or reject every federal law that has an impact on the states. A majority of states is required for consent and currently states consider about two thirds of all federal laws (Döring and Voigt 2006). The power to consent or reject give state governments influence over federal legislation.

\section{II.B. Tax Revenues}

The German governing system has three levels: local, state and federal. The local governments administer the provision of utility services, and manage local infrastructure and welfare benefits. At the state level, governments provide primary, secondary, and university education, manage cultural affairs, policing services, and the administration of justice. The federal government provides national defense, handles international affairs, unemployment benefits, and social security.

The German 'fiscal constitution' is two-tiered. Although the federal and state governments are autonomous fiscal entities, the scope of states’ legislative authority is limited, because many state activities are regulated by federal mandates. Thus, state governments largely do not decide independently what goods and services to provide. Similarly, local governments are not independent of state governments. Although local governments have the right to govern themselves, federal and state laws restrict their fiscal autonomy. Further, local governments have a claim (Finanzausstattungsanspruch) to state funding up to a level that is sufficient to allow 
them to function (Scholz, Maunz, and Düring 2009, 40-41). The subordinate position of the local governments makes them 'subsidiaries' (Geschöpfe) of the states (Zimmermann 2002, 5). ${ }^{10}$ State governments supervise the tasks of local governments and local governments can draw on resources from state governments. ${ }^{11}$

The German constitution mandates that receipts from the most important taxes are distributed between the different levels of government. Based on Article 106 of the German constitution, revenues fall into four groups of taxes and are distributed across levels of government based on the type of tax. First, revenues from joint taxes, which include the value added tax (VAT), the corporate income tax and the personal income tax, are divided between the federal, state, and local governments. Tax rates for those taxes are set at the federal level and these rates are uniform throughout Germany. Second, the federal government keeps revenues from federal taxes such as the insurance tax, the tobacco tax, and the energy tax. Third, states keep revenues from state taxes such as the automobile tax, the land acquisition tax, and the lottery tax. Finally, local governments keep local taxes such as the land tax (Grundsteuer) and the industry tax (Gewerbesteuer). Thus, all levels of government obtain revenues from their own taxes and revenues from joint taxes.

In 2004, overall tax revenues in Germany amounted to $€ 443$ billion. Joint taxes accounted for 68 percent of the overall tax revenue, federal taxes for 19 percent, state taxes for 5 percent and local taxes for 8 percent (Bundesministerium der Finanzen 2005). Consequently, most of the revenues for the state budget do not come from state taxes, but are a result of federal transfers from a portion of joint tax revenues. From 1970 to 2004 between $32 \%$ and $40 \%$ of the

\footnotetext{
${ }^{10}$ Also, see Blankart (2000) and Blankart and Klaiber (2006) for a discussion of how German municipalities are part of the state governments.

${ }^{11}$ For an analysis of the consequences of intra-state equalization transfers for the tax policy of local governments see Büttner (2006).
} 
overall joint tax revenue was distributed to state governments (Bundesministerium der Finanzen 2007).

Although states receive all revenues from state taxes, the federal government sets uniform tax rates across states for all state taxes. Thus states have no influence over their revenues through setting taxes. On the spending side states are subject to federal spending mandates for which goods to allocate resources. But they face no serious constraints in their decisions on the amount of their spending, even if spending exceeds revenues and results in debt (Rodden 2006a).

\section{II.C. Intergovernmental Bailout Transfers}

Redistribution from the federal level to the state level and across states is motivated by article 107 of the German Constitution which mandates “a reasonable equalization of the disparate financial capacities of the Länder.”12 The current federal Financial Equalization Law implements the constitutional mandate and codifies conditions for all transfers. According to the Financial Equalization Law, the intergovernmental transfer system aims at equalizing fiscal revenues per capita across states through a redistribution of state tax revenues and transfers of federal funds. The structure of redistribution has not changed in any essential way since a major federal public finance reform in $1969 .^{13}$ Thus, transfers of resources are institutionalized.

Redistribution through the intergovernmental equalization system, by law, depends on each state's per capita tax revenue relative to all other states. Formula-based intergovernmental transfers are directly determined by the states' fiscal performance. Additional funds from the

\footnotetext{
${ }^{12}$ From the official translation of the German Constituion. The Länder are the German states.

${ }^{13}$ For a historical background on the German Fiscal Equalization Law see Renzsch (1986). In the 1980s some minor changes of the transfer rules occurred. A Constitutional Court ruling in 1994 led to extraordinary supplementary transfers to the states of Bremen and Saarland (Pitlik et al. 2006; Rodden 2003; Rodden 2006a).
} 
federal government can also be given to states with special burdens, which are aimed at reducing financial distress in fiscally weak states. ${ }^{14}$ Because transfers are partly a function of states’ fiscal performance, we refer to these transfers as routine bailouts and institutionalized bailouts.

This fiscal equalization strategy has several elements. First, the German Constitution mandates that at least 75 percent of the value added tax (VAT) receipts from each state be redistributed across all states, so that each state receives the same revenues per capita. This results in a redistribution from states with large VAT revenues per capita to those with few revenues from the VAT. Second, the remaining 25 percent of the VAT receipts are to be redistributed based on a formula set in the Fiscal Equalization Law. Here, fiscally strong states make additional transfers to fiscally weak states. Whether a state is fiscally strong or weak depends on its per capita tax revenues compared to the per capita average of all other states. Third, fiscally strong states make additional equalizing transfers to fiscally weak states. Again, transfers are based on a formula assessing each state's fiscal revenue and comparing it to the average per capita revenue across states. On this stage state tax revenues as well as revenues of the local governments enter the calculation of fiscal strength (Finanzkraft). After all of these transfers have taken place, each state has reached at least 95 percent of the average per capita fiscal strength of all states.

In addition to the aforementioned horizontal redistribution across states, which leads to a redistribution from stronger to weaker states, there is a vertical redistribution of taxpayer funds from the federal government to states (Bundesergänzungszuweisungen). Some of these vertical transfers are formula-based and are designed to close $90 \%$ of the remaining gap in the average

\footnotetext{
${ }^{14}$ We refer to intergovernmental transfers as bailouts, since the transfers increase with a deterioration in fiscal performance.
} 
fiscal capacity per capita across states after the horizontal transfers described in the previous paragraph have taken place.

Vertical transfers are also available to assist fiscally weak states in mitigating the consequences of some special burdens at the state level. For example, there are vertical transfers to the five eastern states of Germany and the city state of Berlin, which were integrated into the transfer system in 1995 after the German reunification in 1990. The official intention of these transfers is the alleviation of the consequences of the German separation. ${ }^{15}$ Other examples are transfer to states to pay for their above average costs of political administration (Kosten politischer Führung $)^{16}$ and transfers are to states with “over-proportional” fiscal burdens causing them to have high expenditures. ${ }^{17}$ While the official intention of some additional transfers is the easement of the transition, states receiving funds for political administration and high fiscal burdens include not only eastern states. Western states, such as Bremen, Niedersachsen, Saarland, Rheinland-Pfalz, Schleswig-Holstein, some of which do not border eastern Germany, also receive these funds. Finally, at various points in time the states Saarland and Bremen received transfers to reduce their debt levels, indicating that vertical transfers are related to fiscal expenditures.

\section{Model the Effect of Malapportionment on Soft Budget Constraints}

In a bargaining game, small states are willing to sell their votes at a lower price than larger states, because at a given price their per capita benefit is larger than the per capita benefit to larger

\footnotetext{
${ }^{15}$ See Gesetz über den Finanzausgleich zwischen Bund und Ländern (Financial Equalization Law) as of 2004,, § 11, paragraph 4.

${ }^{16}$ See Gesetz über den Finanzausgleich zwischen Bund und Ländern (Financial Equalization Law) as of 2004,, § 11, paragraph 3.

${ }^{17}$ See Gesetz über den Finanzausgleich zwischen Bund und Ländern (Financial Equalization Law) as of 2004,, § 11, paragraph 5.
} 
states. For example, Atlas et al. (1995) argue that in the U.S. Senate "a given amount of effort devoted to local benefit seeking (...) will be more beneficial (in per capita terms) to constituents, and hence to a Senator, the less populous the Senator's state is." The same hypothesis applies to the German case. The smaller a state's population, the larger the per capita benefit of a transfer of a certain size to a state. ${ }^{18}$ Because small overrepresented states have a lower supply price for their votes, they can better pursue their goals within the complex structure of interrelations between the federal and the state governments in Germany.

German face soft budget constraints because there is no strict relationship between state expenditure and tax revenues. When a state has expenditures in excess of its revenues, it can expect that the gap will be financed by other states or the federal government, either through the institutionalized bailout system (horizontal and vertical transfers) in which bailouts are a function of the fiscal position of states, or explicitly via additional financial transfers. Because the availability of such financial assistance is built into a state's fiscal decisions, the incentive for sound fiscal policy is weak. While the German tax system limits the taxing authority of the states, soft budget constraints weaken the incentives to close any gap between tax revenues and spending. However, softness of the budget constraints is not uniform across states. Because overrepresented states have more than proportional bargaining power in the Bundesrat and thus a strong expectation of a federal bailout, they have an incentive to pursue a relatively lax budgetary policy and to rely more heavily on transfers than underrepresented states.

\footnotetext{
${ }^{18}$ The equalization scheme makes Germany a special case since, as opposed to the U.S., intergovernmental transfers are mostly regulated by formulae. These formulae are not subject to revision on a regular basis, and one might therefore expect that the distribution of votes in the upper chamber does not have any impact on the degree to which transfers influence the softness of the budget constraints. However, formula-based transfers might not be independent of the legislative bargaining process. Forces that influence the distribution of non-formula based transfers, such as earmarked funds in the U.S., might also be at play when formulas are created, revised, and applied in Germany.
} 
We model the government's behavior facing a choice over the size of the deficit $(d)$. In our simple model a state government's utility $(U)$ increases as deficits widen. Since state taxes are not directly determined at the state level, increased deficits mainly result from increased spending. We assume that utility increases with increasing spending, and thus deficits, because the incumbent state government's reelection probability increases in the size of spending.

However, deficits carry a cost for state governments $(C(d))$. The higher the deficit compared to other states, the higher future taxes and the less satisfied the voters. Further, it becomes more difficult for the states to convince their constituency that general factors, not state-specific factors like spending, caused the deficit. Additionally, high deficits carry a cost because they hurt the reputation of state governments, reducing the likelihood that members of state governments will assume federal office.

The utility costs of higher deficits also depend on the degree of overrepresentation of the state in the Bundesrat $(\Omega)$. The more a state is overrepresented, the smaller are the costs from deficits, since transfers are more readily available due to a superior bargaining position. Thus, a state government faces the following maximization problem:

$$
\max _{d} U(d)-\frac{1}{\Omega} C(d)
$$

with the following first order condition:

$$
\frac{\partial U}{\partial d}-\frac{1}{\Omega} \frac{\partial C}{\partial d}=0
$$

which implies that - assuming the government's utility is concave in deficits, and the utility cost is convex in deficit, or the effect of a marginal increase in deficit on the utility cost function is constant - the more a state is overrepresented, i.e. the larger $(\Omega)$, the larger is the optimal deficit. 
This simple model allows us to formulate several hypotheses. First, the model predicts that overrepresented states will run higher deficits. Overrepresented states have an incentive to create a larger gap between expenditures and tax revenues which can be filled, due to their voting power, through transfers from underrepresented states and the federal government. Second, using a similar logic, we predict that overrepresented states have higher debt per capita. Because of their superior bargaining power in the Bundesrat, overrepresented states are more likely to receive financial support in cases of indebtedness. Therefore, debt comes at a lower price for overrepresented states, giving them an incentive to have higher debt. A corollary of the deficit and debt hypotheses is overrepresented states will be more successful in seeking bailout funds.

We explore several additional hypotheses. We test whether the increases in deficits that are associated with soft budget constraints are due to increases in spending. We separate total state spending into spending on public goods and private goods, and test whether spending on selected state-provided public and private goods increases with the softness of a state's budget constraint. We test whether governments of overrepresented states spend a larger share of their funds on spending categories that have less public good character and rather serve special interests. This test is motivated by the fact that every increase in bailout funds provides the state government with additional room for discretionary maneuver. With additional horizontal and vertical funds received, the costs of catering to organized special interests decreases, which may result in a shift in the mix of private and public goods provided by the state. Finally, we test whether overrepresented states provide public goods less efficiently than underrepresented states. 


\section{Econometric Specification and Data}

We use data from 1970 to 2004 to analyze the effects of soft budget constraints, measured as the overrepresentation in the German Bundesrat, on state total deficit per capita. ${ }^{19}$ We include eastern German states starting with 1995, since this is the first year in which these states were included in the inter-state redistribution system. Our regression specification is

deficit $_{i t}=\alpha$ votespercapita $_{i t}+\beta$ Govt coalition state $_{i t}+\gamma$ Govt opposition state $_{i t}+\boldsymbol{\delta} \mathbf{X}_{i t}+\theta_{i}+\tau_{t}+\mu_{i t}$

The dependent variable, deficit ${ }_{i t}$ is state $i$ 's total deficit per capita at time $t$. This variable is defined as the sum of the primary deficit, VAT transfers, direct horizontal transfers, and vertical transfers as described in section II.C.$^{20}$ The votespercapita ${ }_{\text {it }}$ variable is a state’s per capita number of votes in the Bundesrat. The regression includes for state fixed effects $\theta_{i}$ and year fixed effects $\tau_{t}$. We denote the error term with $\mu_{i t}$. State fixed effects capture all observed and unobserved variables that are constant for the state over time. Thus, these indicator variables also capture state size and average state population density. While the votespercapita ${ }_{i t}$ variable is correlated with state size because smaller states tend to have more votes in the Bundesrat, by controlling for state size via state indicators, we can separate the effect of voting and bargaining power in the Bundesrat from the effect of state size and population density.

Further, we include indicator variables for whether or not the government at the federal level is ruled by the same parties as those at the state level. We define the variable "Govt

\footnotetext{
${ }^{19}$ Our starting year is 1970 because that is the first year after the substantial federal reform in 1969.

${ }^{20}$ The primary deficit used includes state and local level deficits since, as described in section II.B., local governments are not independent of state governments and the amount of federal transfers to states is also based on the finances of local governments which are legally subordinated to the states.
} 
coalition state ${ }_{i t}$ “ as one if the state is governed solely by parties that are in the federal government's ruling coalition, and zero otherwise. Further, we define the variable "Govt opposition state $_{i t}$ " as one if the state is governed solely by parties that are in the opposition on the federal level, and zero otherwise. ${ }^{21}$ Thus, all states with a governing coalition whose parties are in the opposition and in the governing coalition on the federal level serve as the reference group. $^{22,23}$

The vector $\mathbf{X}_{i t}$ includes tax revenue per capita. We include the sum of state and local tax revenues as a proxy of the fiscal revenue measure because both state and local revenues are considered in the official calculation of routine bailouts. We also include total state population because the incentive to run a deficit is lower when the state is large. This is because the larger the state, the greater the incentive to internalize the cost of a bailout (Rodden 2006a). Further, we include population density and the unemployment rate. While the state dummies control for these variables to the extent that they are constant over time, by including these variables explicitly we also control for changes in unemployment, and state population size and density over time.

To test whether overrepresented states receive higher routine bailouts and have higher debt, we substitute various measures for institutionalized bailouts and debt for deficits in equation (3).

Table A1 in the appendix provides means and standard deviations of all data used in this paper. Table A1 also includes variable definitions and sources of data.

\footnotetext{
${ }^{21}$ König and Bräuninger (1997) refer to these states as A-states and B-states.

${ }^{22}$ An example of the left out category is if a state is governed by the CDU and SPD parties and when the federal government is comprised of the CDU while the SPD is in the opposition at the federal level.

${ }^{23}$ Often, the government does not change at the end or the beginning of the year. In these cases we define these variables to equal one when the government formed in the first half of that year. Otherwise we code the election outcomes as effective in the following year.
} 


\section{Results}

Table 2 reports the effect of soft budget constraints on deficits per capita. In this and in most subsequent tables the first column has as its only covariate the softness of the budget constraint, measured as the number of state votes per capita in the Bundesrat. The second column adds covariates measuring the bargaining strength of states, arising from the fact that the parties in the state government may be comprised of the same make up (Government coalition state) or opposite make up (Government opposition state) as the parties in the federal government. The third column adds state and local revenues per capita, which is the measure used according to the German law governing redistribution across states. Column 4 adds other socio-economic controls. The last column adds the interaction term between a number of votes in the Bundesrat and an indicator variable for whether a state is an eastern state. ${ }^{24}$ We include this latter variable to test whether eastern states behave systematically different with respect to overrepresentation as opposed to western states.

The results reported in Table 2 show that the number of votes per capita in the Bundesrat has the predicted effect on deficits per capita. The more a state is overrepresented the larger is its total deficit. The point estimates on Bundesrat votes is statistically significant at the one percent level. For example, the point estimate in Table 2, column 4 indicates that one extra vote per capita increases the deficit by $€ 1.8$ per capita, which is 0.3 percent of the mean of the total deficit. In the regressions the variable "Votes Per Capita” is measured as number of votes per million population multiplied by a factor of 1,000 . Thus, for a state with a population of five million and five seats in the upper chamber, which is close to the seat average, an additional vote

\footnotetext{
${ }^{24}$ Because this indicator variable is a linear combination of the indicators for the eastern states, and therefore already measure the effect of being an eastern state on the dependent variable, we do not include a separate "East" indicator in the regressions.
} 
in the Bundesrat translates into an increase in the "Votes Per Capita" measure by $200{ }^{25}$

Accordingly, the point estimate on "votes per capita" in column 4 of 1.8 predicts that in a state of five million, having one extra seat in the Bundesrat leads to a $€ 360$ higher per capita deficit.

As mentioned in the introduction, we hypothesized that votes of states in the opposition, that have an even higher opportunity cost of voting for the federal government, typically do not have to be bought in order to obtain a majority in the Bundesrat. Similarly, the federal government also does not have to purchase the votes of states that have the same party composition as that of the federal government, since these state governments are likely to vote for the federal government's position in any case. Table 2 shows that the point estimates on "Government coalition state” and "Government opposition state" are negative and statistically significant at the one percent level. These results suggest that states where the state government is only partially made up by parties that govern at the federal level, i.e. the states in the reference group, have higher deficits than states with governments that are either perfectly similar or perfectly dissimilar to the federal government. Thus, states with mixed governments, i.e. governments whose votes are cheaper than votes of governments that are entirely composed of opposition parties at the federal level, have the highest deficits. One explanation for this finding is that states with mixed governments have the strongest expectation that they will be bailed out by the federal government in a financial crises.

As expected, tax revenue, our measure of fiscal capacity as defined by German law, has a negative sign and is statistically significant at the one percent level in all specifications of Table 2. The population variable is not statistically significant, suggesting that increases in population within a state do not affect fiscal policy. The point estimates on population density

\footnotetext{
${ }^{25}$ With a five million state population and with five votes in the Bundesrat the votes per capita variable equals 1,000. When the number of votes in the Bundesrat increase to 6 votes, our independent variable equals 1,200.
} 
are negative and statistically significant, suggesting that the denser a state's population, the lower its deficits. The remaining controls--unemployment and the interaction between votes per capita and eastern states--are not statistically significant.

Next we examine the effect of overrepresentation on debt. Table 3 shows the results. In all specifications more votes in the Bundesrat lead to higher debt. With a point estimate of 5.2 (Table 3, column 4), using the previous example, one extra vote in the Bundesrat for a state with five million people implies a higher debt of about $€ 1,040$ per capita. These results lend further support to the hypothesis that the softer the budget constraint, the less sound the fiscal policy. The measures on bargaining strength based on the party composition of government are statistically significant and have the predicted negative signs in Table 3, columns 2 and 3, but are not statistically significant in columns 4 and 5.

Next we examine the effect of soft budget constraints on routine bailouts. In Tables 4A, $4 \mathrm{~B}$, and $4 \mathrm{C}$ we test for the determinants of the transfer components separately. ${ }^{26}$ The three components are: indirect horizontal transfers due to the VAT redistribution according to population (Table 4A), direct horizontal transfers between the states which depend on the fiscal performance of the state (Table 4B), and vertical transfers which also depend on fiscal performance and for which the federal government has the largest discretion as to how to allocate these transfers (Table 4C). The number of votes per capita in the Bundesrat in all three tables is statistically significant at the one percent level, except for one specification in the VAT transfer regression (Table 4A), which is statistically significant at the ten percent level. Votes per capita have the largest marginal impact in regressions that have as their dependent variable routine bailouts that are distributed with the largest discretion. The associated point estimates

\footnotetext{
${ }^{26}$ When we combine all transfers and use this measure as the dependent variable we find very similar results as those reported when we run separate regressions for each of the three components of overall transfers.
} 
range from 0.29 for direct horizontal transfers (Table 4B) to 1.15 for federal transfers (Table 4C).

Following up on the example above, for a state with a population of five million, one extra vote translates into an €114 increase in value added tax redistribution (Table 4A, column 4), a €58 increase in horizontal transfers (Table 4B, column 4), and a $€ 230$ increase in vertical transfers (Table 4C, column 4).

The finding that of all transfers, transfers from federal to states governments have the largest point estimate of the three types of transfers can be explained with the discretionary nature of these transfers. Federal transfers are to a small part formula-based and largely conditional on the presence of 'special burdens.' In 2004, twenty percent of these transfers were based on the fiscal strength of the recipient states, and the remainder was provided on a more discretionary basis, i.e. on whether a state faced an "excessive" fiscal burden.

We also find that the estimated elasticities for the vote per capita variable are the highest for the vertical transfers. ${ }^{27}$ Further, the beta coefficients also suggest that transfers are more responsive to changes in the votes per capita variable with beta coefficients increasing as the discretionary element of the transfers increases. Whereas a one standard deviation change in votes per capita leads to a 1.33 standard deviations change in VAT (Table 4A), and a 1.74 standard deviations change in horizontal transfers (Table 4B), a one standard deviation change in votes per capita induces a 4.13 standard deviations change in federal transfers (Table 4C). ${ }^{28}$

We also find that states' bargaining power, based on the political make-up of the state government as opposed federal government matters for bailouts (Tables 4): states that are only

\footnotetext{
${ }^{27}$ The level of year-to-year discretion for the transfers based on special burdens is reduced by the fact that these transfers are mostly approved for several years in advance.

${ }^{28}$ The elasticities show a similar picture. A one percent change in the votes per capita variable induces a 7 percent change in horizontal transfers and a 9.8 percent change in vertical transfers. Maybe surprisingly, the elasticity for VAT transfers is with 8.56 percent higher than that for horizontal transfers. To put these results further into perspective, the corresponding elasticity for the effect of votes per capita on the total deficit per capita is 4.7.
} 
partially comprised of parties which are members of the federal government receive more funds at each stage of the intergovernmental transfer system. This is consistent with the hypothesis that these governments can extract a higher supply price for their votes in the German Bundesrat.

While we find that overrepresented states run higher deficits (Table 2), the results do not allow for conclusions whether these findings are driven by lower taxes or more spending, and, if it is more spending, which spending categories contribute to the increase in total spending. But given that the German institutional structure does not allow states to set their own tax rates, and that states only have discretion over the spending side of the budget, deficits are predicted to be due to additional expenditures, no lower tax revenues.

For the question of which expenditures are most sensitive to soft budget constraints, we focus on seven spending categories, which we can plausibly divide into public good spending and private good spending. As public goods, we consider spending on political administration (approximately sixty-five percent of which are wages for state government employees), education, police, and culture. As private goods, those most likely to benefit special interests, we consider spending on agriculture, regional aids, and state-run enterprises.

We estimate the following regression for each of the seven spending categories:

$$
\text { spending }_{i t}=\alpha \cdot \text { votespercapita }_{i t}+\gamma \cdot \mathbf{X}_{i t}+\theta_{i}+\tau_{t}+\mu_{i t}
$$

where spending measures either total state government spending per capita or spending for each of the spending categories. As in the previous regressions, the variable "votespercapita" measures the votes in the upper chamber divided by state population. We include per capita income among the variables in the $\mathbf{X}_{i t}$ vector.

The results in Table 5 show that our measure for the softness of budget constraints, votes per capita, is positively correlated with overall spending. The point estimates on overall spending 
are statistically significant, suggesting that the increase in deficits and debt found in previous tables, is driven by an increase in spending. Though not reported in the tables, we also estimated this specification using per capita state tax revenues as the dependent variable and found that the point estimates on "votespercapita" are positive and not statistically significant. Given that German states have limited taxing authority and that state tax revenues are small, the finding that revenues are uncorrelated with overrepresentation in the Bundesrat is not surprising.

Table 5 shows that the point estimates on per capita spending are positive for six spending categories. ${ }^{29}$ Five of these estimates are statistically significant. Votes per capita has the largest marginal effect on regional aid and state enterprises, both of which are largely private goods. We find the next largest marginal effect for government administration. The marginal effect of spending on police and culture is one third or less the size of the effect of spending on political administration. Education expenditures and agricultural expenditures are not affected by soft budget constraints and the size of the coefficient on agriculture is very small and negative. These findings show that, with the exception of agriculture, the largest spending increases occur for private goods, followed by spending on government administration. The closer the good is to public goods, like police and education, the lower the marginal effects of votes per capita.

State governments face pressure from interest groups to increase spending and alter regulations to their benefit. A state government with a soft budget constraint--and thus more resources--may be more likely to placate rent seeking interest groups. Thus, we next investigate whether overrepresented states spend a smaller portion of their budgets on public goods.

The results in Table 6 are based on a similar specification to those in Table 5, but the dependent variable is public goods spending and private goods spending as a share of the state

\footnotetext{
${ }^{29}$ These categories account for roughly fifty percent of the overall state budget. The bulk of the remaining spending categories is welfare spending (for example, "Soziale Sicherung, soziale Kriegsfolgeaufgaben, Wiedergutmachung" and "Jugendhilfe").
} 
budget. The first four columns in Table 6 report results for the goods we consider to be closer to public goods. We find that for all public goods categories the expectation of a bailout has a negative effect on the share of public goods spending. Among these categories the point estimates for relative spending on education, police, and culture are statistically significant.

The last three columns of Table 6 contain the categories that we considered private goods and measures of favors to special interests. Here, overrepresentation has a positive effect on relative spending and the point estimates are statistically significant for agriculture and regional aids. Overrepresented states devote a larger proportion of their budgets on these latter categories. The coefficient for state enterprises is positive but overrepresentation has no statistically significant effect on the proportion of funds spent on state enterprises. Together, Tables 5 and 6 suggest that overrepresentation leads to higher expenditures in almost all spending categories, but the amount spent, as a share of the total budget, decreases for public goods and increases for private goods.

Table 7 examines the effect of soft budget constraints on government efficiency. We measure efficiency by dividing spending by the relevant input. We estimate a similar specification as in Table 4, but use as the dependent variables police spending per crime, hospital spending per patient and primary and secondary education expenditures per student. ${ }^{30} \mathrm{We}$ selected these three measures based on availability of a plausible input measure for a spending category.

Table 7 shows that the point estimates on votes per capita are positive and statistically significant with police spending and hospital spending as the dependent variable. The point estimate in the education expenditures regression is also positive, but statistically insignificant.

\footnotetext{
${ }^{30}$ We did not include hospital spending in the regressions in Tables 5 and 6 due to the difficulty of classifying it either as a private or public good. However, when estimating a regression similar as in Table 5, we find that per capita hospital spending increase with overrepresentation in the German upper chamber.
} 
Assuming services stemming from three expenditure categories are comparable across states, the results in Table 7 suggest that states with soft budget constraints spend their funds less efficiently than other states. States with soft budget constraints spend more money per case, i.e. crime committed and patients treated, for roughly equivalent services.

\section{Conclusion}

Theoretically, soft budget constraints give states an incentive to conduct unsustainable fiscal policies. However, bailout expectations cannot be directly observed. We use a plausibly exogenous variation in states' political bargaining power--arising from malapportionment in the German upper chamber of parliament--to identify the effect of soft budget constraints on the size of deficits and debt. Our results show that overrepresentation of states in the German Bundesrat is one determinant of unsustainable fiscal policies. As overrepresentation increases, a state’s bargaining power increases and with it the softness of the budget constraint. The softer a state's budget constraint the higher the deficit and the larger the debt. This systematic evidence is consistent with the anecdotal evidence that the two most overrepresented states in the Bundesrat, Bremen and Saarland, were bailed out by the federal government initially in 1992 and received additional bailout funds annually until 2004.

Institutionalized bailouts, which, according to many pages of German laws and regulations are determined by formula, are sensitive to the political power of state governments. States that are overrepresented and states that have superior bargaining power due to the constellation of party representation in the federal vs. state government receive the most funds in all three types of institutionalized bailouts. The political bargaining power is most effective for those bailout funds that have the highest discretionary element. 
Overrepresentation and the associated bailout expectation also impact how state government funds are spent. The larger the expectation of a bailout, the higher the amount spent in a number of spending categories, and special interests are most likely to benefit from this additional spending. We also find that bailout expectations lead to less efficient state government service provision. 


\section{References}

Atlas, Cary M., Thomas W. Gilligan, Robert J. Hendershott and Mark A. Zupan. 1995. "Slicing the Federal Government Net Spending Pie: Who Wins, Who Loses, and Why.” The American Economic Review 85(3): 624-629.

Blankart, Charles B. 2000. “The Process of Government Centralization: A Constitutional View.” Constitutional Political Economy 11: 27-39.

Blankart, Charles B. and Achim Klaiber. 2006. "Subnational Government Organisation and Public Debt Crises.” Economic Affairs 26(3): 48-54.

Boex, Jameson and Jorge Martinez-Vazquez. 2004. “The Determinants of the Incidence of Intergovernmental Grants: A Survey of the International Experience.” Public Finance and Management 4(4): 454-479.

Büttner, Thies. 2006. “The incentive effect of fiscal equalization transfers on tax policy.” Journal of Public Economics 90(3): 477-497.

Bundesministerium der Finanzen. 2005. Monatsbericht des Bundesministerium der Finanzen Juli 2005.

Bundesministerium der Finanzen. 2007. Monatsbericht des Bundesministerium der Finanzen August 2007.

Denzau, Arthur T. and Michael C. Munger. 1986. "Legislators and Interest Groups: How Unorganized Interests Get Represented.” The American Political Science Review 80(1): 89-106.

Dewatripont, Mathias and Eric Maskin. 1995. "Credit and Efficiency in Centralized and Decentralized Economies." Review of Economic Studies 62(4): 541-555.

Döring, Thomas and Stefan Voigt. 2006. "Reforming Federalism German Style. A First Step in the Right Direction.” Intereconomics 41(4): 201-208.

Grossman, Philip J. 1994. “A Political Theory of Intergovernmental Transfers.” Public Choice 78(3-4): 295-303.

Hauk, William R. and Romain Wacziarg. 2007. “Small States, Big Pork.” Quarterly Journal of Political Sciences 2: 95-106.

Hoover, Gary A. and Paul Pecorino. 2005. “The Political Determinants of Federal Expenditure at the State Level.” Public Choice 123(1): 95-113.

Knight, Brian. 2005. "Legislative Representation, Bargaining Power, and the Distribution of Federal Funds: Evidence from the U.S. Senate.” NBER Working Paper No. 10385 
König, Thomas and Thomas Bräuninger. 1997. "Wie wichtig sind die Länder für die Politik der Bundesregierung bei Einspruchs- und Zustimmungsgesetzen?” Zeitschrift für Parlamentsfragen 28(4): 605-28.

Kornai, Janos. 1979. "Resource-Constrained versus Demand-Constrained Systems.” Econometrica 47(4): 801-819.

Kornai, Janos. 1986. “The Soft Budget Constraint.” Kyklos 39(1): 3-30.

Kornai, Janos. 1998. "The Place of the Soft Budget Constraint Syndrome in Economic Theory.” Journal of Comparative Economics 26(1): 11-17.

Kornai, Janos, Eric Maskin and Gerard Roland. 2003. "Understanding the Soft Budget Constraint.” Journal of Economic Literature 41(4): 1095-1136.

Kröger, Klaus. 1989. “Die Entstehung des Grundgesetzes.” Neue Juritische Wochenschrift: 1318-1324.

Lee, Frances E. 1998. "Representation and Public Policy: The Consequences of Senate Appointment for the Geographic Distribution of Federal Funds.” The Journal of Politics 60(1): 34-62.

Pitlik, Hans, Günther Schmid and Harald Strotmann. 2001. "Bargaining Power of Smaller States in Germany’s Länderfinanzausgleich 1979-1990.” Public Choice 109(1-2): 183-201.

Pitlik, Hans, Friedrich Schneider and Harald Strotmann. 2006. “Legislative Malappointment and the Politicization of Germany’s Intergovernmental Transfer System.” Public Finance Review 34: 637-662.

Renzsch, Wolfgang. 1986. "Neuordnung des bundesstaatlichen Finanzausgleichs. Finanzverfassung und Foederalismus, Probleme und Perspektiven”. Gegenwartskunde 35: 499-533.

Rodden, Jonathan. 2002. "The Dilemma of Fiscal Federalism: Grants and Fiscal Performance around the World.” American Journal of Political Science 46(3): 670-687.

Rodden, Jonathan. 2003. “Soft Budget Constraint and German Federalism.” In Fiscal Decentralization and the Challenge of Hard Budget Constraints, edited by Jonathan Rodden, Gunnar Eskeland, and Jennie Litvack. Cambridge: MIT Press, 161-186.

Rodden, Jonathan. 2006a. Hamilton's Paradox. Cambridge: Cambridge University Press.

Rodden, Jonathan. 2006b. "Achieving Fiscal Discipline in Federations: Germany and the EMU.” In Fiscal Policy Surveillance in Europe, edited by Peter Wierts, Servaas Deroose, Elena Flores and Alessandro Turrini. New York: Palgrave Macmillan: 137-160. 
Samuels, David and Richard Snyder. 2001. "The Value of a Vote: Malapportionment in Comparative Perspective.” British Journal of Political Science 31(4): 651-671.

Scholz, Rupert, Theodor Maunz and Günter Düring. 2009. Kommentar zum Grundgesetz. München: C.H. Beck.

Stehn, Sven Jari and Analisa Fedelino. 2009. "Fiscal Incentive Effects of the German Fiscal Equalization System." IMF Working Paper no. 124.

Stratmann, Thomas. 1992. “Are Contributions Rational? Untangling Strategies of Political Action Committees.” Journal of Political Economy, 100(3): 647-64.

Vigneault, Marianne. 2007. “Grants and Soft Budget Constraints.” In Intergovernmental Fiscal Transfers. Principles and Practice, edited by Robin Broadway and Anwar Shah. Washington, D.C.: The World Bank. 133-171.

Weingast, Barry R. 2009. "Second generation fiscal federalism: The implications of fiscal incentives.”. Journal of Urban Economics. 65(3): 237-336.

Wildasin, David E. 1997. "Externalities and Bailouts: Hard and Soft Budget Constraints in Intergovernmental Fiscal Relations.” World Bank Policy Research Working Paper 1843.

Zimmermann, H. (2002): “Notwendigkeiten und Perspektiven einer Gemeindefinanzreform in Deutschland.” Druckfassung eines Vortags auf dem Symposium „Kommunale Steuerund Finanzreform“ zur Feier des 75-jährigen Gründungsjubiläums des Finanzwissenschaftlichen Forschungsinstituts an der Universität zu Köln. 
Table 1

Distribution of Seats in the Upper Chamber (Bundesrat) of the German Parliament in 2004

\begin{tabular}{|c|c|c|c|}
\hline State & $\begin{array}{l}\text { Population in } \\
\text { millions }\end{array}$ & $\begin{array}{c}\text { Seats in the } \\
\text { upper chamber }\end{array}$ & $\begin{array}{c}\text { Seats per } \\
\text { population in } \\
\text { millions }\end{array}$ \\
\hline Baden-Württemberg & 10.72 & 6 & 0.56 \\
\hline Bavaria & 12.44 & 6 & 0.48 \\
\hline Berlin & 3.39 & 4 & 1.18 \\
\hline Brandenburg & 2.57 & 4 & 1.56 \\
\hline Bremen & 0.66 & 3 & 4.55 \\
\hline Hamburg & 1.73 & 3 & 1.73 \\
\hline Hesse & 6.10 & 5 & 0.82 \\
\hline Mecklenburg-Vorpommern & 1.72 & 3 & 1.74 \\
\hline Lower Saxony & 8.00 & 6 & 0.75 \\
\hline North Rhine-Westphalia & 18.08 & 6 & 0.33 \\
\hline Rhineland-Palatinate & 4.06 & 4 & 0.99 \\
\hline Saarland & 1.06 & 3 & 2.83 \\
\hline Saxony & 4.30 & 4 & 0.93 \\
\hline Saxony-Anhalt & 2.50 & 4 & 1.60 \\
\hline Schleswig-Holstein & 2.83 & 4 & 1.41 \\
\hline Thuringia & 2.36 & 4 & 1.69 \\
\hline
\end{tabular}


Table 2

Effects of Overrepresentation on the Total Deficits (The dependent variable is total deficit per capita)

\begin{tabular}{|c|c|c|c|c|c|}
\hline & 1 & 2 & 3 & 4 & 5 \\
\hline Votes Per Capita & $\begin{array}{c}2.500^{* * *} \\
(0.565)\end{array}$ & $\begin{array}{c}2.534^{* * *} \\
(0.464)\end{array}$ & $\begin{array}{c}2.386^{* * *} \\
(0.396)\end{array}$ & $\begin{array}{c}1.832 * * * \\
(0.707)\end{array}$ & $\begin{array}{c}1.891^{* * *} \\
(0.694)\end{array}$ \\
\hline $\begin{array}{l}\text { Government Coalition } \\
\text { State }\end{array}$ & & $\begin{array}{c}-430.4^{* * *} \\
(87.440)\end{array}$ & $\begin{array}{c}-451.2^{* * *} \\
(86.790)\end{array}$ & $\begin{array}{l}-401.6 * * * \\
(111.300)\end{array}$ & $\begin{array}{l}-390.8 * * * \\
(115.300)\end{array}$ \\
\hline $\begin{array}{l}\text { Government Opposition } \\
\text { State }\end{array}$ & & $\begin{array}{c}-576.6 * * * \\
(82.840)\end{array}$ & $\begin{array}{c}-522.5^{* * *} \\
(88.280)\end{array}$ & $\begin{array}{c}-488.2^{* * *} \\
(98.270)\end{array}$ & $\begin{array}{l}-479.1^{* * *} \\
(100.700)\end{array}$ \\
\hline Tax Revenue Per Capita & & & $\begin{array}{c}-1.141 * * * \\
(0.136)\end{array}$ & $\begin{array}{c}-1.094 * * * \\
(0.147)\end{array}$ & $\begin{array}{c}-1.104 * * * \\
(0.149)\end{array}$ \\
\hline Population & & & & $\begin{array}{l}-0.125 \\
(0.087)\end{array}$ & $\begin{array}{l}-0.134 \\
(0.091)\end{array}$ \\
\hline Population Density & & & & $\begin{array}{c}-2.617^{* *} \\
(1.269)\end{array}$ & $\begin{array}{c}-2.504^{* *} \\
(1.245)\end{array}$ \\
\hline Unemployment & & & & $\begin{array}{c}-23.3 \\
(20.970)\end{array}$ & $\begin{array}{c}-19.86 \\
(21.510)\end{array}$ \\
\hline Votes Per Capita*Eastern States & & & & & $\begin{array}{l}-1.621 \\
(1.469)\end{array}$ \\
\hline State Fixed Effects & Yes & Yes & Yes & Yes & Yes \\
\hline Year Fixed Effects & Yes & Yes & Yes & Yes & Yes \\
\hline Observations & 410 & 410 & 410 & 410 & 410 \\
\hline R-squared & 0.816 & 0.849 & 0.878 & 0.883 & 0.883 \\
\hline
\end{tabular}

The dependent variable is the deficit per capita in a state by year. The measure of deficits includes the state's primary budget deficit plus transfers from the equalization scheme. Regressions are based on annual data by state from 1970 to 2004. Robust standard errors in parenthesis below point estimates. ${ }^{*} \mathrm{p}<0.10,{ }^{* *} \mathrm{p}<0.05,{ }^{* * *} \mathrm{p}<0.01$. 
Table 3

Effects of Overrepresentation on Debt

\begin{tabular}{|c|c|c|c|c|c|}
\hline & 1 & 2 & 3 & 4 & 5 \\
\hline Votes Per Capita & $\begin{array}{c}8.666^{* * *} \\
(1.936)\end{array}$ & $\begin{array}{l}7.300 * * * \\
(1.896)\end{array}$ & $\begin{array}{l}7.480 * * * \\
(1.813)\end{array}$ & $\begin{array}{l}5.245^{* *} \\
(2.207)\end{array}$ & $\begin{array}{l}6.088 * * * \\
(2.235)\end{array}$ \\
\hline $\begin{array}{l}\text { Government Coalition } \\
\text { State }\end{array}$ & & $\begin{array}{l}-1027.0 * * * \\
(279.800)\end{array}$ & $\begin{array}{l}-1001.0 * * * \\
(282.800)\end{array}$ & $\begin{array}{c}267.6 \\
(240.000)\end{array}$ & $\begin{array}{c}423.2^{*} \\
(242.000)\end{array}$ \\
\hline $\begin{array}{l}\text { Government Opposition } \\
\text { State }\end{array}$ & & $\begin{array}{l}-630.2 * * \\
(280.900)\end{array}$ & $\begin{array}{l}-695.8 * * \\
(280.100)\end{array}$ & $\begin{array}{c}-274.1 \\
(204.000)\end{array}$ & $\begin{array}{c}-145.0 \\
(199.300)\end{array}$ \\
\hline Tax Revenue Per Capita & & & $\begin{array}{c}1.384 \\
(1.031)\end{array}$ & $\begin{array}{c}2.565 * * * \\
(0.613)\end{array}$ & $\begin{array}{c}2.427 * * * \\
(0.578)\end{array}$ \\
\hline Population & & & & $\begin{array}{l}-4.040 * * * \\
(0.341)\end{array}$ & $\begin{array}{c}-4.163 * * * \\
(0.346)\end{array}$ \\
\hline Population Density & & & & $\begin{array}{c}1.688 \\
(4.231)\end{array}$ & $\begin{array}{c}3.307 \\
(4.248)\end{array}$ \\
\hline Unemployment & & & & $\begin{array}{l}485.8 * * * \\
(95.570)\end{array}$ & $\begin{array}{l}534.9 * * * \\
(100.700)\end{array}$ \\
\hline Votes Per Capita*Eastern States & & & & & $\begin{array}{l}-23.18 * * * \\
(6.355)\end{array}$ \\
\hline State Fixed Effects & Yes & Yes & Yes & Yes & Yes \\
\hline Year Fixed Effects & Yes & Yes & Yes & Yes & Yes \\
\hline Observations & 410 & 410 & 410 & 410 & 410 \\
\hline R-squared & 0.866 & 0.87 & 0.872 & 0.934 & 0.936 \\
\hline
\end{tabular}

The dependent variable is debt per capita in a state by year. The measure of deficits includes the state's primary budget deficit plus transfers from the equalization scheme. Regressions are based on annual data by state from 1970 to 2004 . Robust standard errors in parenthesis below point estimates. ${ }^{*} \mathrm{p}<0.10,{ }^{* *} \mathrm{p}<0.05,{ }^{* * *} \mathrm{p}<0.01$. 
Table 4A

Effects of overrepresentation on Bailouts: VAT Transfers

\begin{tabular}{|c|c|c|c|c|c|}
\hline & 1 & 2 & 3 & 4 & 5 \\
\hline Votes Per Capita & $\begin{array}{c}0.969 * * * \\
(0.232)\end{array}$ & $\begin{array}{c}0.937 * * * \\
(0.269)\end{array}$ & $\begin{array}{c}0.867 * * * \\
(0.228)\end{array}$ & $\begin{array}{l}0.572^{*} \\
(0.344)\end{array}$ & $\begin{array}{c}0.454 \\
(0.349)\end{array}$ \\
\hline $\begin{array}{l}\text { Government Coalition } \\
\text { State }\end{array}$ & & $\begin{array}{c}-267.5 * * * \\
(75.500)\end{array}$ & $\begin{array}{c}-277.5^{* * *} \\
(76.780)\end{array}$ & $\begin{array}{c}-370.0^{* * *} \\
(85.820)\end{array}$ & $\begin{array}{c}-391.9 * * * \\
(88.810)\end{array}$ \\
\hline $\begin{array}{l}\text { Government Opposition } \\
\text { State }\end{array}$ & & $\begin{array}{c}-331.2 * * * \\
(81.330)\end{array}$ & $\begin{array}{c}-305.3^{* * *} \\
(88.780)\end{array}$ & $\begin{array}{c}-327.1^{* * *} \\
(91.190)\end{array}$ & $\begin{array}{c}-345.2 * * * \\
(93.060)\end{array}$ \\
\hline Tax Revenue Per Capita & & & $\begin{array}{c}-0.547 * * * \\
(0.166)\end{array}$ & $\begin{array}{c}-0.639 * * * \\
(0.124)\end{array}$ & $\begin{array}{c}-0.619 * * * \\
(0.123)\end{array}$ \\
\hline Population & & & & $\begin{array}{c}0.506 * * * \\
(0.061)\end{array}$ & $\begin{array}{c}0.523 * * * \\
(0.063)\end{array}$ \\
\hline Population Density & & & & $\begin{array}{l}-0.958 \\
(0.762)\end{array}$ & $\begin{array}{l}-1.185 \\
(0.771)\end{array}$ \\
\hline Unemployment & & & & $\begin{array}{c}-20.53 \\
(12.990)\end{array}$ & $\begin{array}{c}-27.44^{* *} \\
(12.810)\end{array}$ \\
\hline Votes Per Capita*Eastern States & & & & & $\begin{array}{c}3.256 * * * \\
(0.889)\end{array}$ \\
\hline State Fixed Effects & Yes & Yes & Yes & Yes & Yes \\
\hline Year Fixed Effects & Yes & Yes & Yes & Yes & Yes \\
\hline Observations & 410 & 410 & 410 & 410 & 410 \\
\hline R-squared & 0.67 & 0.708 & 0.731 & 0.782 & 0.785 \\
\hline
\end{tabular}

The dependent variable is the net value added tax transfers per capita (which can be positive or negative) that an individual state receives or pays to other states per year. Regressions are based on annual data by state from 1970 to 2004. Robust standard errors in parenthesis below point estimates. ${ }^{*} \mathrm{p}<0.10,{ }^{* *} \mathrm{p}<0.05,{ }^{* * *} \mathrm{p}<0.01$. 
Table 4B

Effects of overrepresentation on Bailouts: Horizontal Transfers

\begin{tabular}{|c|c|c|c|c|c|}
\hline & 1 & 2 & 3 & 4 & 5 \\
\hline Votes Per Capita & $\begin{array}{c}0.545^{* * *} \\
(0.125)\end{array}$ & $\begin{array}{c}0.538^{* * *} \\
(0.105)\end{array}$ & $\begin{array}{c}0.496 * * * \\
(0.091)\end{array}$ & $\begin{array}{c}0.287 * * * \\
(0.103)\end{array}$ & $\begin{array}{c}0.319 * * * \\
(0.105)\end{array}$ \\
\hline $\begin{array}{l}\text { Government Coalition } \\
\text { State }\end{array}$ & & $\begin{array}{c}-75.32 * * * \\
(16.150)\end{array}$ & $\begin{array}{c}-81.20 * * * \\
(13.030)\end{array}$ & $\begin{array}{c}-37.96 * * * \\
(11.040)\end{array}$ & $\begin{array}{c}-32.03 * * * \\
(10.760)\end{array}$ \\
\hline $\begin{array}{l}\text { Government Opposition } \\
\text { State }\end{array}$ & & $\begin{array}{c}-94.22 * * * \\
(16.490)\end{array}$ & $\begin{array}{c}-78.94 * * * \\
(13.120)\end{array}$ & $\begin{array}{c}-60.09 * * * \\
(10.220)\end{array}$ & $\begin{array}{c}-55.17 * * * \\
(9.844)\end{array}$ \\
\hline Tax Revenue Per Capita & & & $\begin{array}{c}-0.322 * * * \\
(0.031)\end{array}$ & $\begin{array}{c}-0.283 * * * \\
(0.025)\end{array}$ & $\begin{array}{c}-0.288 * * * \\
(0.025)\end{array}$ \\
\hline Population & & & & $\begin{array}{c}-0.116 * * * \\
(0.017)\end{array}$ & $\begin{array}{c}-0.121 * * * \\
(0.017)\end{array}$ \\
\hline Population Density & & & & $\begin{array}{c}-0.580 * * * \\
(0.191)\end{array}$ & $\begin{array}{c}-0.518 * * * \\
(0.190)\end{array}$ \\
\hline Unemployment & & & & $\begin{array}{l}8.441 * * \\
(3.486)\end{array}$ & $\begin{array}{c}10.32 * * * \\
(3.519)\end{array}$ \\
\hline Votes Per Capita*Eastern States & & & & & $\begin{array}{c}-0.883 * * * \\
(0.243)\end{array}$ \\
\hline State Fixed Effects & Yes & Yes & Yes & Yes & Yes \\
\hline Year Fixed Effects & Yes & Yes & Yes & Yes & Yes \\
\hline Observations & 410 & 410 & 410 & 410 & 410 \\
\hline R-squared & 0.82 & 0.84 & 0.896 & 0.928 & 0.929 \\
\hline
\end{tabular}

The dependent variable is horizontal (i.e. from some states to other states) transfers per capita per state (which can be positive or negative) in the course of the equalization scheme received by states or paid to other states per year. Regressions are based on annual data by state from 1970 to 2004. Robust standard errors in parenthesis below point estimates. ${ }^{*} \mathrm{p}<0.10,{ }^{* *} \mathrm{p}<0.05$, $* * * \mathrm{p}<0.01$. 
Table 4C

Effects of overrepresentation on Bailouts: Vertical Transfers

\begin{tabular}{|c|c|c|c|c|c|}
\hline & 1 & 2 & 3 & 4 & 5 \\
\hline Votes Per Capita & $\begin{array}{c}1.145 * * * \\
(0.253)\end{array}$ & $\begin{array}{c}1.116 * * * \\
(0.219)\end{array}$ & $\begin{array}{c}1.064 * * * \\
(0.212)\end{array}$ & $\begin{array}{c}1.153^{* * *} \\
(0.213)\end{array}$ & $\begin{array}{c}1.090^{* * *} \\
(0.217)\end{array}$ \\
\hline Government Coalition State & & $\begin{array}{c}-136.7^{* * *} \\
(45.080)\end{array}$ & $\begin{array}{c}-144.0^{* * * *} \\
(42.810)\end{array}$ & $\begin{array}{c}-70.73 * * \\
(32.760)\end{array}$ & $\begin{array}{c}-82.31 * * \\
(33.640)\end{array}$ \\
\hline Government Opposition State & & $\begin{array}{c}-162.5^{* * *} \\
(45.840)\end{array}$ & $\begin{array}{c}-143.5 * * * \\
(44.940)\end{array}$ & $\begin{array}{c}-119.3 * * \\
(35.580)\end{array}$ & $\begin{array}{l}-128.9 * * \\
(36.590)\end{array}$ \\
\hline Tax Revenue Per Capita & & & $\begin{array}{c}-0.400^{* * *} \\
(0.069)\end{array}$ & $\begin{array}{c}-0.326^{* * *} \\
(0.051)\end{array}$ & $\begin{array}{c}-0.315^{* * *} \\
(0.053)\end{array}$ \\
\hline Population & & & & $\begin{array}{c}-0.420^{* * * *} \\
(0.044)\end{array}$ & $\begin{array}{c}-0.411^{* * * *} \\
(0.044)\end{array}$ \\
\hline Population Density & & & & $\begin{array}{c}-0.371 \\
(0.316)\end{array}$ & $\begin{array}{c}-0.491 \\
(0.329)\end{array}$ \\
\hline Unemployment & & & & $\begin{array}{l}-6.242 \\
(8.983)\end{array}$ & $\begin{array}{l}-9.901 \\
(8.618)\end{array}$ \\
\hline Votes Per Capita*Eastern States & & & & & $\begin{array}{c}1.725^{* * *} \\
(0.597)\end{array}$ \\
\hline State Fixed Effects & Yes & Yes & Yes & Yes & Yes \\
\hline Year Fixed Effects & Yes & Yes & Yes & Yes & Yes \\
\hline Observations & 410 & 410 & 410 & 410 & 410 \\
\hline R-squared & 0.672 & 0.693 & 0.723 & 0.804 & 0.806 \\
\hline
\end{tabular}

The dependent variable is vertical (i.e. transfers from the federal government) to states per year. Regressions are based on annual data by state from 1970 to 2004. Robust standard errors in parenthesis below point estimates. ${ }^{*} \mathrm{p}<0.10,{ }^{* *} \mathrm{p}<0.05,{ }^{* * *} \mathrm{p}<0.01$. 
Table 5

The Effects of overrepresentation on state-level per capita spending

\begin{tabular}{|c|c|c|c|c|c|c|c|c|}
\hline & Total Spending & $\begin{array}{c}\text { Government } \\
\text { Administration }\end{array}$ & Education & Police & Culture & \multicolumn{3}{|c|}{ Agriculture Regional Aid State Enterprises } \\
\hline $\begin{array}{l}\text { Government Coalition } \\
\text { State }\end{array}$ & $\begin{array}{c}-72.11 \\
(44.370)\end{array}$ & $\begin{array}{l}-2.922 \\
(2.636)\end{array}$ & $\begin{array}{c}1.491 \\
(6.062)\end{array}$ & $\begin{array}{c}0.722 \\
(1.934)\end{array}$ & $\begin{array}{c}-6.392 * * * \\
(1.506)\end{array}$ & $\begin{array}{l}-3.261 * * \\
(1.519)\end{array}$ & $\begin{array}{l}-17.98 * * * \\
(6.25)\end{array}$ & $\begin{array}{c}-17.33^{* *} \\
(6.767)\end{array}$ \\
\hline Tax Revenue Per Capita & $\begin{array}{c}0.944^{* * *} \\
(0.082)\end{array}$ & $\begin{array}{c}0.0426 * * * \\
(0.00629\end{array}$ & $\begin{array}{c}0.0668 * * * \\
(0.0141)\end{array}$ & $\begin{array}{r}0.0605 * * * \\
(0.00464)\end{array}$ & $\begin{array}{r}0.0275^{* * *} \\
(0.00501)\end{array}$ & $\begin{array}{c}-0.00452^{* *} \\
(0.00223)\end{array}$ & $\begin{array}{l}-0.0124 \\
(0.0118)\end{array}$ & $\begin{array}{c}0.0401 \\
(0.0298)\end{array}$ \\
\hline Population & $\begin{array}{c}-0.626 * * * \\
(0.060)\end{array}$ & $\begin{array}{c}-0.0427 * * * \\
(0.00395\end{array}$ & $\begin{array}{l}0.0183 * * \\
(0.00763)\end{array}$ & $\begin{array}{c}-0.0364 * * * \\
(0.00275)\end{array}$ & $\begin{array}{l}-0.00125 \\
(0.0029)\end{array}$ & $\begin{array}{l}0.0196 * * * \\
(0.00192)\end{array}$ & $\begin{array}{c}-0.0569 * * * \\
(0.0103)\end{array}$ & $\begin{array}{c}-0.0269 * * \\
(0.0122)\end{array}$ \\
\hline Unemployment & $\begin{array}{c}12.02 \\
(12.560)\end{array}$ & $\begin{array}{l}-1.102 \\
(0.857\end{array}$ & $\begin{array}{l}-2.657 \\
(2.417)\end{array}$ & $\begin{array}{l}2.818 * * * \\
(0.602)\end{array}$ & $\begin{array}{c}-1.659 * * * \\
(0.514)\end{array}$ & $\begin{array}{c}-2.746 * * * \\
(0.41)\end{array}$ & $\begin{array}{c}-9.876^{* * *} \\
(2.416)\end{array}$ & $\begin{array}{l}-1.709 \\
(2.474)\end{array}$ \\
\hline Votes Per Capita*Eastern States & $\begin{array}{c}-5.234^{* * *} \\
(0.900)\end{array}$ & $\begin{array}{c}-0.419 * * * \\
(0.0898\end{array}$ & $\begin{array}{l}-0.522 * \\
(0.283)\end{array}$ & $\begin{array}{l}0.0632 \\
(0.05)\end{array}$ & $\begin{array}{l}-0.0935 \\
(0.0571)\end{array}$ & $\begin{array}{l}0.306 * * * \\
(0.0645)\end{array}$ & $\begin{array}{c}-0.765^{* *} \\
(0.349)\end{array}$ & $\begin{array}{c}-0.579 * * * \\
(0.152)\end{array}$ \\
\hline $\begin{array}{l}\text { State Fixed Effects } \\
\text { Year Fixed Effects }\end{array}$ & $\begin{array}{l}\text { Yes } \\
\text { Yes }\end{array}$ & $\begin{array}{l}\text { Yes } \\
\text { Yes }\end{array}$ & $\begin{array}{l}\text { Yes } \\
\text { Yes }\end{array}$ & $\begin{array}{l}\text { Yes } \\
\text { Yes }\end{array}$ & $\begin{array}{l}\text { Yes } \\
\text { Yes }\end{array}$ & $\begin{array}{l}\text { Yes } \\
\text { Yes }\end{array}$ & $\begin{array}{l}\text { Yes } \\
\text { Yes }\end{array}$ & $\begin{array}{l}\text { Yes } \\
\text { Yes }\end{array}$ \\
\hline $\begin{array}{l}\text { Observations } \\
\text { R-squared }\end{array}$ & $\begin{array}{c}410 \\
0.989\end{array}$ & $\begin{array}{c}410 \\
0.989\end{array}$ & $\begin{array}{c}410 \\
0.988\end{array}$ & $\begin{array}{c}410 \\
0.992\end{array}$ & $\begin{array}{c}410 \\
0.974\end{array}$ & $\begin{array}{c}410 \\
0.962\end{array}$ & $\begin{array}{c}370 \\
0.905\end{array}$ & $\begin{array}{l}410 \\
0.73\end{array}$ \\
\hline
\end{tabular}

All dependent variables are measured per capita. Regressions are based on annual data by state from 1970 to 2004. Robust standard errors in parenthesis below point estimates. ${ }^{*} \mathrm{p}<0.10,{ }^{* *} \mathrm{p}<0.05,{ }^{* * *} \mathrm{p}<0.01$. 
Table 6

The Effects of overrepresentation on state-level relative spending

\begin{tabular}{|c|c|c|c|c|c|c|c|}
\hline & $\begin{array}{c}\text { Government } \\
\text { Administration }\end{array}$ & Education & Police & Culture & Agriculture & Regional Aid & State Enterprises \\
\hline Votes Per Capita & $\begin{array}{c}-0.00471 \\
(0.006)\end{array}$ & $\begin{array}{l}-0.0614^{* * *} \\
(0.009)\end{array}$ & $\begin{array}{l}-0.0210^{* * *} \\
(0.004)\end{array}$ & $\begin{array}{c}-0.00933 * * * \\
(0.002)\end{array}$ & $\begin{array}{c}0.0283^{* * *} \\
(0.004)\end{array}$ & $\begin{array}{l}0.0506 * * * \\
(0.009)\end{array}$ & $\begin{array}{l}0.0447 \\
(0.074)\end{array}$ \\
\hline $\begin{array}{l}\text { Government Coalition } \\
\text { State }\end{array}$ & $\begin{array}{c}-1.706 * * \\
(0.845)\end{array}$ & $\begin{array}{l}-2.044 \\
(1.602)\end{array}$ & $\begin{array}{l}-0.471 \\
(0.647)\end{array}$ & $\begin{array}{l}-0.539 * \\
(0.284)\end{array}$ & $\begin{array}{l}-0.976^{*} \\
(0.570)\end{array}$ & $\begin{array}{c}-4.690 * * * \\
(1.325)\end{array}$ & $\begin{array}{c}-1.92 \\
(5.466)\end{array}$ \\
\hline $\begin{array}{l}\text { Government Opposition } \\
\text { State }\end{array}$ & $\begin{array}{l}-2.193^{* * *} \\
(0.825)\end{array}$ & $\begin{array}{c}1.586 \\
(1.490)\end{array}$ & $\begin{array}{l}-0.373 \\
(0.504)\end{array}$ & $\begin{array}{l}-0.0439 \\
(0.253)\end{array}$ & $\begin{array}{l}-0.641 \\
(0.506)\end{array}$ & $\begin{array}{c}-5.190 * * * \\
(1.313)\end{array}$ & $\begin{array}{c}0.214 \\
(2.898)\end{array}$ \\
\hline Tax Revenue Per Capita & $\begin{array}{l}0.0119 * * * \\
(0.002)\end{array}$ & $\begin{array}{c}0.00508 \\
(0.003)\end{array}$ & $\begin{array}{c}-0.00510 * * * \\
(0.001)\end{array}$ & $\begin{array}{l}0.000288 \\
(0.001)\end{array}$ & $\begin{array}{l}0.00507 * * * \\
\quad(0.001)\end{array}$ & $\begin{array}{l}0.00297 \\
(0.002)\end{array}$ & $\begin{array}{l}0.0092 \\
(0.010)\end{array}$ \\
\hline Population & $\begin{array}{c}0.00163 \\
(0.001)\end{array}$ & $\begin{array}{l}0.0125^{* * *} \\
(0.002)\end{array}$ & $\begin{array}{l}0.00397 * * * \\
(0.001)\end{array}$ & $\begin{array}{c}0.000502 \\
(0.000)\end{array}$ & $\begin{array}{l}-0.00310^{* * *} \\
(0.001)\end{array}$ & $\begin{array}{l}-0.00502 * * * \\
(0.002)\end{array}$ & $\begin{array}{c}0.000482 \\
(0.003)\end{array}$ \\
\hline Population Density & $\begin{array}{l}0.0147 \\
(0.013)\end{array}$ & $\begin{array}{c}-0.0337 * \\
(0.020)\end{array}$ & $\begin{array}{c}-0.00165 \\
(0.010)\end{array}$ & $\begin{array}{c}-0.00825^{*} \\
(0.004)\end{array}$ & $\begin{array}{c}-0.000365 \\
(0.007)\end{array}$ & $\begin{array}{l}-0.028 \\
(0.017)\end{array}$ & $\begin{array}{l}-0.0156 \\
(0.064)\end{array}$ \\
\hline Unemployment & $\begin{array}{l}0.0297 \\
(0.269)\end{array}$ & $\begin{array}{c}-0.967 * \\
(0.559)\end{array}$ & $\begin{array}{l}-0.114 \\
(0.160)\end{array}$ & $\begin{array}{c}-0.489 * * * \\
(0.090)\end{array}$ & $\begin{array}{c}-0.380 * * * \\
(0.141)\end{array}$ & $\begin{array}{c}-1.203^{* * *} \\
(0.458)\end{array}$ & $\begin{array}{l}-1.807 \\
(2.335)\end{array}$ \\
\hline $\begin{array}{l}\text { Votes Per Capita*Eastern } \\
\text { States }\end{array}$ & $\begin{array}{l}0.0213 \\
(0.022)\end{array}$ & $\begin{array}{l}0.0452 \\
(0.053)\end{array}$ & $\begin{array}{l}0.0858^{* * * *} \\
(0.013)\end{array}$ & $\begin{array}{c}0.000175 \\
(0.010)\end{array}$ & $\begin{array}{l}0.0161 \\
(0.014)\end{array}$ & $\begin{array}{c}-0.136 * * \\
(0.065)\end{array}$ & $\begin{array}{l}-0.0605 \\
(0.044)\end{array}$ \\
\hline $\begin{array}{l}\text { State Fixed Effects } \\
\text { Year Fixed Effects }\end{array}$ & $\begin{array}{l}\text { Yes } \\
\text { Yes }\end{array}$ & $\begin{array}{l}\text { Yes } \\
\text { Yes }\end{array}$ & $\begin{array}{l}\text { Yes } \\
\text { Yes }\end{array}$ & $\begin{array}{l}\text { Yes } \\
\text { Yes }\end{array}$ & $\begin{array}{l}\text { Yes } \\
\text { Yes }\end{array}$ & $\begin{array}{l}\text { Yes } \\
\text { Yes }\end{array}$ & $\begin{array}{l}\text { Yes } \\
\text { Yes }\end{array}$ \\
\hline $\begin{array}{l}\text { Observations } \\
\text { R-squared }\end{array}$ & $\begin{array}{c}410 \\
0.832\end{array}$ & $\begin{array}{c}410 \\
0.901\end{array}$ & $\begin{array}{l}410 \\
0.91\end{array}$ & $\begin{array}{c}410 \\
0.929\end{array}$ & $\begin{array}{c}410 \\
0.953\end{array}$ & $\begin{array}{c}370 \\
0.901\end{array}$ & $\begin{array}{c}410 \\
0.245\end{array}$ \\
\hline
\end{tabular}

All dependent variables are measured as a share of total expenditures. Regressions are based on annual data by state from 1970 to 2004 . Robust standard errors in parenthesis below point estimates. ${ }^{*} \mathrm{p}<0.10,{ }^{* *} \mathrm{p}<0.05,{ }^{* * *} \mathrm{p}<0.01$. 
Table 7

The Effects of Overrepresentation on Government Efficiency

\begin{tabular}{|c|c|c|c|}
\hline & $\begin{array}{l}\text { Police Spending per } \\
\text { Crime }\end{array}$ & $\begin{array}{l}\text { Hospital Spending } \\
\text { per Patient }\end{array}$ & $\begin{array}{l}\text { Primary and } \\
\text { Secondary Education } \\
\text { Spending per Student }\end{array}$ \\
\hline Votes Per Capita & $\begin{array}{c}0.940 * * * \\
(0.326)\end{array}$ & $\begin{array}{c}0.771^{* * *} \\
(0.223)\end{array}$ & $\begin{array}{l}0.0125 \\
(0.369)\end{array}$ \\
\hline Government Coalition State & $\begin{array}{c}-16.91 \\
(31.560)\end{array}$ & $\begin{array}{c}24.41 \\
(45.400)\end{array}$ & $\begin{array}{c}19.4 \\
(58.030)\end{array}$ \\
\hline Government Opposition State & $\begin{array}{c}-0.69 \\
(25.340)\end{array}$ & $\begin{array}{l}-71.57^{*} \\
(42.560)\end{array}$ & $\begin{array}{c}33.27 \\
(49.950)\end{array}$ \\
\hline Tax Revenue Per Capita & $\begin{array}{c}-0.532 * * * \\
(0.133)\end{array}$ & $\begin{array}{c}0.14 \\
(0.088)\end{array}$ & $\begin{array}{c}0.641^{* * *} \\
(0.139)\end{array}$ \\
\hline Population & $\begin{array}{c}0.337 * * * \\
(0.045)\end{array}$ & $\begin{array}{l}0.114 * * \\
(0.058)\end{array}$ & $\begin{array}{l}-0.127^{*} \\
(0.068)\end{array}$ \\
\hline Population Density & $\begin{array}{l}1.931^{*} \\
(0.995)\end{array}$ & $\begin{array}{c}-0.843^{* *} \\
(0.398)\end{array}$ & $\begin{array}{c}3.853 * * * \\
(1.042)\end{array}$ \\
\hline Unemployment & $\begin{array}{c}-46.38 * * * \\
(10.080)\end{array}$ & $\begin{array}{c}-34.90 * * * \\
(12.900)\end{array}$ & $\begin{array}{c}73.53^{* * *} \\
(15.650)\end{array}$ \\
\hline $\begin{array}{l}\text { Votes Per Capita*Eastern } \\
\text { States }\end{array}$ & $\begin{array}{c}6.072 * * * \\
(0.846)\end{array}$ & $\begin{array}{l}-3.318 \\
(2.480)\end{array}$ & $\begin{array}{c}16.67 * * * \\
(1.979)\end{array}$ \\
\hline $\begin{array}{l}\text { State Fixed Effects } \\
\text { Year Fixed Effects }\end{array}$ & $\begin{array}{l}\text { Yes } \\
\text { Yes }\end{array}$ & $\begin{array}{l}\text { Yes } \\
\text { Yes }\end{array}$ & $\begin{array}{l}\text { Yes } \\
\text { Yes }\end{array}$ \\
\hline $\begin{array}{l}\text { Observations } \\
\text { R-squared }\end{array}$ & $\begin{array}{c}400 \\
0.973\end{array}$ & $\begin{array}{c}370 \\
0.895\end{array}$ & $\begin{array}{c}350 \\
0.982\end{array}$ \\
\hline
\end{tabular}

The dependent variable is spending per capita in the three categories per state per year.

Regressions are based on annual data by state from 1970 to 2004. Robust standard errors in parenthesis below point estimates. ${ }^{*} \mathrm{p}<0.10,{ }^{* *} \mathrm{p}<0.05,{ }^{* * *} \mathrm{p}<0.01$. 


\section{Appendix}

Table A1

\begin{tabular}{|c|c|c|c|c|c|c|}
\hline Variable & Description & n & Mean & $\begin{array}{l}\text { Stan. } \\
\text { Dev. }\end{array}$ & Source & Construction \\
\hline $\begin{array}{l}\text { Deficit per } \\
\text { Capita }\end{array}$ & $\begin{array}{l}\text { Total deficit per capita } \\
\text { including budget deficits } \\
\text { and transfers from the } \\
\text { equalization scheme }\end{array}$ & 410 & 560.992 & 910.655 & $\begin{array}{l}\text { Federal statistical office } \\
\text { (Fachserie 14, Reihe } 3.1 . \\
\text { Rechnungsergebnisse des } \\
\text { öffentlichen Gesamthaushalts) } \\
\text { and Federal Ministry of } \\
\text { Finance ("Zweite Verordnung } \\
\text { zue Durchfuehrung des } \\
\text { Gesetzes ueber den } \\
\text { Finanzausgleich zwischen } \\
\text { Bund und Laendern im } \\
\text { Ausgleichsjahr") }\end{array}$ & $\begin{array}{l}\text { Sum of Primary Deficit } \\
\text { per Capita, VAT Transfers } \\
\text { per Capita, Horizontal } \\
\text { Transfers per Capita, and } \\
\text { Vertical Transfers per } \\
\text { capita in Euro }\end{array}$ \\
\hline $\begin{array}{l}\text { Sum of all } \\
\text { Transfers per } \\
\text { Capita }\end{array}$ & $\begin{array}{l}\text { Sum of all transfers } \\
\text { received by states per } \\
\text { capita }\end{array}$ & 410 & 322.493 & 789.351 & $\begin{array}{l}\text { Federal statistical office and } \\
\text { Federal Ministry of Finance } \\
\text { ("Zweite Verordnung zue } \\
\text { Durchfuehrung des Gesetzes } \\
\text { ueber den Finanzausgleich } \\
\text { zwischen Bund und Laendern } \\
\text { im Ausgleichsjahr") }\end{array}$ & $\begin{array}{l}\text { Sum of VAT Transfers per } \\
\text { Capita, Horizontal } \\
\text { Transfers per Capita, and } \\
\text { Vertical Transfers per } \\
\text { capita in Euro }\end{array}$ \\
\hline $\begin{array}{l}\text { VAT Transfers } \\
\text { per Capita }\end{array}$ & $\begin{array}{l}\text { Value added tax } \\
\text { transfers per capita }\end{array}$ & 410 & 95.542 & 486.911 & $\begin{array}{l}\text { Federal Ministry of Finance, } \\
\text { "Zweite Verordnung zue } \\
\text { Durchfuehrung des Gesetzes } \\
\text { ueber den Finanzausgleich } \\
\text { zwischen Bund und Laendern } \\
\text { im Ausgleichsjahr" }\end{array}$ & $\begin{array}{l}\text { (Länderanteile Ust } \\
\text { insgesamt - Länderanteil } \\
\text { am örtlichen } \\
\text { Umsatzsteueraufkommen } \\
\text { - abgerechnete Anteile an } \\
\text { der Einfuhrumsatzsteuer) / } \\
\text { population }\end{array}$ \\
\hline
\end{tabular}




\begin{tabular}{|c|c|c|c|c|c|c|}
\hline $\begin{array}{l}\text { Horizontal } \\
\text { Transfers per } \\
\text { Capita }\end{array}$ & $\begin{array}{l}\text { Horizontal transfers per } \\
\text { capita per state in the } \\
\text { course of the } \\
\text { equalization scheme }\end{array}$ & 410 & 58.618 & 186.923 & Federal Statistical Office & $\begin{array}{l}\text { Horizontal transfers / } \\
\text { population }\end{array}$ \\
\hline $\begin{array}{l}\text { Vertical } \\
\text { Transfers per } \\
\text { Capita }\end{array}$ & $\begin{array}{l}\text { Vertical transfers per } \\
\text { capita per state }\end{array}$ & 410 & 168.333 & 315.480 & Federal Statistical Office & $\begin{array}{l}\text { Vertical transfers / } \\
\text { population }\end{array}$ \\
\hline $\begin{array}{l}\text { Debt per } \\
\text { Capita }\end{array}$ & Debt per capita & 410 & 4.953 & 4.305 & Federal Statistical Office & $\begin{array}{l}\text { (Kreditmarktschulden im } \\
\text { weiteren Sinne + Schulden } \\
\text { bei öffentlichen } \\
\text { Haushalten + } \\
\text { Kreditähnliche } \\
\text { Rechtsgeschäfte + Innere } \\
\text { Darlehen + } \\
\text { Kassenverstärkungskredite } \\
\text { + Bürgschaften, Garantien } \\
\text { und sonstige } \\
\text { Gewährleistungen) / } \\
\text { population }\end{array}$ \\
\hline $\begin{array}{l}\text { Votes Per } \\
\text { Capita }\end{array}$ & $\begin{array}{l}\text { Seats/votes per capita in } \\
\text { the upper chamber }\end{array}$ & 410 & 1429.524 & 1130.122 & $\begin{array}{l}\text { Archives of the Bundesrat and } \\
\text { the Federal Statistical Office }\end{array}$ & $\begin{array}{l}\text { Votes / } \\
\text { population*1000000 }\end{array}$ \\
\hline $\begin{array}{l}\text { Government } \\
\text { Coalition State }\end{array}$ & $\begin{array}{l}\text { States governed solely } \\
\text { by parties that are also } \\
\text { part of the federal } \\
\text { government's ruling } \\
\text { coalition }\end{array}$ & 410 & 0.341 & 0.475 & $\begin{array}{l}<\text { www.election.de }>\text {, accessed } \\
\text { on } 15 \text { September } 2009\end{array}$ & $\begin{array}{l}\text { Coalition counted as } \\
\text { governing coalition for a } \\
\text { certain state in a certain } \\
\text { year if in power for more } \\
\text { than half of the calendar } \\
\text { year }\end{array}$ \\
\hline
\end{tabular}




\begin{tabular}{|c|c|c|c|c|c|c|}
\hline $\begin{array}{l}\text { Government } \\
\text { Opposition } \\
\text { State }\end{array}$ & $\begin{array}{l}\text { States governed solely } \\
\text { by parties that are part of } \\
\text { the opposition on the } \\
\text { federal level }\end{array}$ & 410 & 0.471 & 0.500 & $\begin{array}{l}<\text { www.election.de }>\text {, accessed } \\
\text { on } 15 \text { September } 2009\end{array}$ & $\begin{array}{l}\text { Coalition counted as } \\
\text { governing coalition for a } \\
\text { certain state in a certain } \\
\text { year if in power for more } \\
\text { than half of the calendar } \\
\text { year }\end{array}$ \\
\hline Mixed State & $\begin{array}{l}\text { States with a governing } \\
\text { coalition whose parties } \\
\text { are represented in the } \\
\text { opposition and the } \\
\text { governing coalition on } \\
\text { the federal level }\end{array}$ & 410 & 0.188 & 0.391 & $\begin{array}{l}<\text { www.election.de }>\text {, accessed } \\
\text { on } 15 \text { September } 2009\end{array}$ & $\begin{array}{l}\text { Coalition counted as } \\
\text { governing coalition for a } \\
\text { certain state in a certain } \\
\text { year if in power for more } \\
\text { than half of the calendar } \\
\text { year }\end{array}$ \\
\hline $\begin{array}{l}\text { Tax Revenue } \\
\text { per Capita }\end{array}$ & Tax revenue per capita & 410 & 1117.735 & 664.996 & $\begin{array}{l}\text { Federal Ministry of Finance, } \\
\text { "Zweite Verordnung zue } \\
\text { Durchfuehrung des Gesetzes } \\
\text { ueber den Finanzausgleich } \\
\text { zwischen Bund und Laendern } \\
\text { im Ausgleichsjahr" }\end{array}$ & $\begin{array}{l}\text { (Steuern nach dem } \\
\text { Aufkommen + } \\
\text { Gemeindeanteil an Est. } \\
\text { und Zinsabschlagsteuer + } \\
\text { Umsatzsteuer der } \\
\text { Gemeinden + Sonstige } \\
\text { Gemeindesteuern + } \\
\text { Grundsteuer A + } \\
\text { Grundsteuer B + } \\
\text { Gewerbesteuer - } \\
\text { Gewerbesteuerumlage im } \\
\text { LFA) / population }\end{array}$ \\
\hline Population & State population & 410 & 5678.140 & 4890.148 & Federal Statistical Office & in 1000 \\
\hline $\begin{array}{l}\text { Population } \\
\text { Density }\end{array}$ & $\begin{array}{l}\text { Population per square } \\
\text { kilometer }\end{array}$ & 410 & 628.481 & 834.397 & Federal Statistical Office & Population / km^2 * 1000 \\
\hline Unemployment & Unemployment rate & 410 & 9.064 & 5.375 & Federal Statistical Office & \\
\hline
\end{tabular}




\begin{tabular}{|c|c|c|c|c|c|c|}
\hline Vote East & $\begin{array}{l}\text { Interaction of votes per } \\
\text { capita in the upper } \\
\text { chamber and if state is } \\
\text { an eastern state joining } \\
\text { the federation in } 1990\end{array}$ & 410 & 206.959 & 512.162 & & \\
\hline $\begin{array}{l}\text { Political } \\
\text { Organization } \\
\text { Per Capita }\end{array}$ & $\begin{array}{l}\text { State budget expenses on } \\
\text { political administration } \\
\text { per capita }\end{array}$ & 410 & 222.455 & 120.534 & $\begin{array}{l}\text { Federal Statistical Office, } \\
\text { "Fachserie 14, Reihe 3.1. } \\
\text { Rechnungsergebnisse des } \\
\text { öffentlichen } \\
\text { Gesamthaushalts" }\end{array}$ & $\begin{array}{l}\text { State budget expenses for } \\
\text { political organization / } \\
\text { population }\end{array}$ \\
\hline $\begin{array}{l}\text { Education Per } \\
\text { Capita }\end{array}$ & $\begin{array}{l}\text { State budget expenses on } \\
\text { primary and secondary } \\
\text { education per capita }\end{array}$ & 410 & 420.887 & 224.745 & $\begin{array}{l}\text { Federal Statistical Office, } \\
\text { "Fachserie 14, Reihe 3.1. } \\
\text { Rechnungsergebnisse des } \\
\text { öffentlichen } \\
\text { Gesamthaushalts" }\end{array}$ & $\begin{array}{l}\text { State budget expenses for } \\
\text { primary and secondary } \\
\text { education / population }\end{array}$ \\
\hline $\begin{array}{l}\text { Police Per } \\
\text { Capita }\end{array}$ & $\begin{array}{l}\text { State budget expenses on } \\
\text { policing per capita }\end{array}$ & 410 & 148.443 & 97.321 & $\begin{array}{l}\text { Federal Statistical Office, } \\
\text { "Fachserie 14, Reihe 3.1. } \\
\text { Rechnungsergebnisse des } \\
\text { öffentlichen } \\
\text { Gesamthaushalts" }\end{array}$ & $\begin{array}{l}\text { State budget expenses for } \\
\text { police / population }\end{array}$ \\
\hline $\begin{array}{l}\text { Culture Per } \\
\text { Capita }\end{array}$ & $\begin{array}{l}\text { State budget expenses on } \\
\text { cultural activities per } \\
\text { capita }\end{array}$ & 410 & 60.731 & 45.595 & $\begin{array}{l}\text { Federal Statistical Office, } \\
\text { "Fachserie 14, Reihe 3.1. } \\
\text { Rechnungsergebnisse des } \\
\text { öffentlichen } \\
\text { Gesamthaushalts" }\end{array}$ & $\begin{array}{l}\text { State budget expenses for } \\
\text { cultural activities / } \\
\text { population }\end{array}$ \\
\hline $\begin{array}{l}\text { Agriculture Per } \\
\text { Capita }\end{array}$ & $\begin{array}{l}\text { State budget expenses on } \\
\text { agriculture per capita }\end{array}$ & 410 & 40.522 & 38.636 & $\begin{array}{l}\text { Federal Statistical Office, } \\
\text { "Fachserie 14, Reihe 3.1. }\end{array}$ & $\begin{array}{l}\text { State budget expenses for } \\
\text { agriculturen/ population }\end{array}$ \\
\hline
\end{tabular}


Rechnungsergebnisse des öffentlichen

Gesamthaushalts"

$\begin{array}{ll}\text { Regional Per } & \begin{array}{l}\text { State budget expenses on } \\ \text { regional aids such as } \\ \text { Capita }\end{array} \\ & \text { infrastructure per capita }\end{array}$

State

Enterprises Per

Capita

Hospital Per

Capita

State budget expenses on

hospitals per capita

410

136.079

state enterprises per

capita

410

71.157

63.788

3.788 Federal Statistical Office, "Fachserie 14, Reihe 3.1.

Rechnungsergebnisse des öffentlichen

Gesamthaushalts"

"Fachserie 14, Reihe 31.

Rechnungsergebnisse des öffentlichen

Gesamthaushalts"

Federal Statistical Office,

"Fachserie 14, Reihe 3.1.

Rechnungsergebnisse des

öffentlichen

Gesamthaushalts"

$\begin{array}{ll}\text { Relative } & \begin{array}{l}\text { Proportion of overall } \\ \text { state budget spent on }\end{array} \\ \text { Political } & \text { political administration }\end{array}$

Relative

Education

\section{Proportion of overall} state budget spent on primary and secondary education
11.984 Federal Statistical Office, "Fachserie 14, Reihe 3.1.

Rechnungsergebnisse des öffentlichen

Gesamthaushalts"

$410 \quad 143.726$

21.289 Federal Statistical Office, "Fachserie 14, Reihe 3.1. Rechnungsergebnisse des öffentlichen

Gesamthaushalts"
State budget expenses for regional aid / population

State budget expenses for state enterprises /

population

State budget expenses for hospitals / population

State budget expenses for political organization / total state budget $* 1000$

State budget expenses for primary and secondary education / total state budget $* 1000$ 


\begin{tabular}{|c|c|c|c|c|c|c|}
\hline Relative Police & $\begin{array}{l}\text { Proportion of overall } \\
\text { state budget spent on } \\
\text { policing }\end{array}$ & 410 & 46.718 & 7.232 & $\begin{array}{l}\text { Federal Statistical Office, } \\
\text { "Fachserie 14, Reihe } 3.1 . \\
\text { Rechnungsergebnisse des } \\
\text { öffentlichen } \\
\text { Gesamthaushalts" }\end{array}$ & $\begin{array}{l}\text { State budget expenses for } \\
\text { police / total state budget } \\
* 1000\end{array}$ \\
\hline $\begin{array}{l}\text { Relative } \\
\text { Culture }\end{array}$ & $\begin{array}{l}\text { Proportion of overall } \\
\text { state budget spent on } \\
\text { cultural activities }\end{array}$ & 410 & 18.370 & 5.263 & $\begin{array}{l}\text { Federal Statistical Office, } \\
\text { "Fachserie 14, Reihe 3.1. } \\
\text { Rechnungsergebnisse des } \\
\text { öffentlichen } \\
\text { Gesamthaushalts" }\end{array}$ & $\begin{array}{l}\text { State budget expenses for } \\
\text { cultural activities / total } \\
\text { state budget } * 1000\end{array}$ \\
\hline $\begin{array}{l}\text { Relative } \\
\text { Agriculture }\end{array}$ & $\begin{array}{l}\text { Proportion of overall } \\
\text { state budget spent on } \\
\text { agriculture }\end{array}$ & 410 & 14.929 & 9.973 & $\begin{array}{l}\text { Federal Statistical Office, } \\
\text { "Fachserie 14, Reihe } 3.1 . \\
\text { Rechnungsergebnisse des } \\
\text { öffentlichen } \\
\text { Gesamthaushalts" }\end{array}$ & $\begin{array}{l}\text { State budget expenses for } \\
\text { agriculturen/ total state } \\
\text { budget } * 1000\end{array}$ \\
\hline $\begin{array}{l}\text { Relative } \\
\text { Regional Aid }\end{array}$ & $\begin{array}{l}\text { Proportion of overall } \\
\text { state budget spent on } \\
\text { regional aids such as } \\
\text { infrastructure }\end{array}$ & 370 & 17.422 & 17.071 & $\begin{array}{l}\text { Federal Statistical Office, } \\
\text { "Fachserie 14, Reihe 3.1. } \\
\text { Rechnungsergebnisse des } \\
\text { öffentlichen } \\
\text { Gesamthaushalts", starting in } \\
1974\end{array}$ & $\begin{array}{l}\text { State budget expenses for } \\
\text { regional aid / total state } \\
\text { budget } * 1000\end{array}$ \\
\hline $\begin{array}{l}\text { Relative State } \\
\text { Enterprises }\end{array}$ & $\begin{array}{l}\text { Proportion of overall } \\
\text { state budget spent on } \\
\text { state owned enterprises }\end{array}$ & 410 & 26.470 & 35.127 & $\begin{array}{l}\text { Federal Statistical Office, } \\
\text { "Fachserie 14, Reihe } 3.1 . \\
\text { Rechnungsergebnisse des } \\
\text { öffentlichen } \\
\text { Gesamthaushalts" }\end{array}$ & $\begin{array}{l}\text { State budget expenses for } \\
\text { state enterprises / total } \\
\text { state budget } * 1000\end{array}$ \\
\hline
\end{tabular}




\begin{tabular}{|c|c|c|c|c|c|c|}
\hline $\begin{array}{l}\text { Relative } \\
\text { Hospitals }\end{array}$ & $\begin{array}{l}\text { Proportion of overall } \\
\text { state budget spent on } \\
\text { hospitals }\end{array}$ & 410 & 48.712 & 32.526 & $\begin{array}{l}\text { Federal Statistical Office, } \\
\text { "Fachserie 14, Reihe } 3.1 . \\
\text { Rechnungsergebnisse des } \\
\text { öffentlichen } \\
\text { Gesamthaushalts" }\end{array}$ & $\begin{array}{l}\text { State budget expenses for } \\
\text { hospitals / total state } \\
\text { budget } * 1000\end{array}$ \\
\hline $\begin{array}{l}\text { Police } \\
\text { Spending per } \\
\text { Crime }\end{array}$ & $\begin{array}{l}\text { Police expenses per } \\
\text { documented crime in the } \\
\text { year before in Euro }\end{array}$ & 400 & 173.919 & 88.357 & $\begin{array}{l}\text { Police Crime Statistics of the } \\
\text { German Federal Republic }\end{array}$ & $\begin{array}{l}\text { State budget expenses for } \\
\text { policing / number of } \\
\text { criminal cases }\end{array}$ \\
\hline $\begin{array}{l}\text { Hospital } \\
\text { Spending per } \\
\text { Patient }\end{array}$ & $\begin{array}{l}\text { Hospital expenses per } \\
\text { documented patient in } \\
\text { Euro }\end{array}$ & 370 & 5948.393 & 5713.048 & $\begin{array}{l}\text { Federal Statistical Office } \\
\text { "Fachserie } 12 \text { Reihe } 6.1 \\
\text { Grunddaten der } \\
\text { Krankenhaeuser und } \\
\text { Vorsorge- oder } \\
\text { Rehabilitationseinrichtungen", } \\
\text { from } 1990 \text { onwards there is } \\
\text { no individual data for the city } \\
\text { states, for } 2000 \text { there are no } \\
\text { data for Mecklenburg- } \\
\text { Vorpommern and Saarland }\end{array}$ & $\begin{array}{l}\text { State budget expenses on } \\
\text { hospitals / number of } \\
\text { patients in hospitals }\end{array}$ \\
\hline $\begin{array}{l}\text { Primary and } \\
\text { Secondary } \\
\text { Education } \\
\text { Spending per } \\
\text { Student }\end{array}$ & $\begin{array}{l}\text { Primary and secondary } \\
\text { education expenses per } \\
\text { student in Euro }\end{array}$ & 320 & 4328.207 & 1598.889 & $\begin{array}{l}\text { Federal Statistical Office, } \\
\text { "Allgemeinbildende Schulen } \\
\text { Fachserie } 11 \text { Reihe 1", } \\
\text { starting in } 1980\end{array}$ & $\begin{array}{l}\text { State budget expenses for } \\
\text { primary and secondary } \\
\text { education / number of } \\
\text { pupils }\end{array}$ \\
\hline
\end{tabular}




\section{CESifo Working Paper Series}

for full list see www.cesifo-group.org/wp

(address: Poschingerstr. 5, 81679 Munich, Germany, office@cesifo.de)

2765 Pierre M. Picard and David E. Wildasin, Labor Market Pooling, Outsourcing and Labor Contracts, August 2009

2766 Stefan Voigt and Lorenz Blume, The Economic Effects of Federalism and Decentralization - A Cross-Country Assessment, August 2009

2767 David S. Jacks, Christopher M. Meissner and Dennis Novy, Trade Booms, Trade Busts, and Trade Costs, August 2009

2768 Mario Jametti and Thomas von Ungern-Sternberg, Hurricane Insurance in Florida, August 2009

2769 Alessandro Balestrino, Kind of Black: The Musicians' Labour Market in Italy, August 2009

2770 Yosr Abid Fourati and Cathal O’Donoghue, Eliciting Individual Preferences for Pension Reform, August 2009

2771 Christian Breuer and Chang Woon Nam, VAT on Intra-Community Trade and Bilateral Micro Revenue Clearing in the EU, August 2009

2772 Choudhry Tanveer Shehzad, Jakob De Haan and Bert Scholtens, Growth and Earnings Persistence in Banking Firms: A Dynamic Panel Investigation, August 2009

2773 Erdal Yalcin, Uncertain Productivity Growth and the Choice between FDI and Export, August 2009

2774 Klaus Abberger, Wolfgang Nierhaus and Shynar Shaikh, Findings of the Signal Approach for Financial Monitoring in Kazakhstan, September 2009

2775 Sascha O. Becker, Francesco Cinnirella and Ludger Woessmann, The Trade-off between Fertility and Education: Evidence from before the Demographic Transition, September 2009

2776 Thomas Aronsson and Erkki Koskela, Optimal Income Taxation, Outsourcing and Policy Cooperation in a Dynamic Economy, September 2009

2777 Joel Slemrod, Old George Orwell Got it Backward: Some Thoughts on Behavioral Tax Economics, September 2009

2778 Cagri Seda Kumru and Athanasios C. Thanopoulos, Social Security Reform and Temptation, September 2009 
2779 Alessandro Bucciol and Roel M. W. J. Beetsma, Inter- and Intra-generational Consequences of Pension Buffer Policy under Demographic, Financial and Economic Shocks, September 2009

2780 Eduardo Strube and Marcelo Resende, Complementarity of Innovation Policies in the Brazilian Industry: An Econometric Study, September 2009

2781 Henry Tulkens and Vincent van Steenberghe, "Mitigation, Adaptation, Suffering": In Search of the Right Mix in the Face of Climate Change, September 2009

2782 Maria L. Loureiro, Anna Sanz-de-Galdeano and Daniela Vuri, Smoking Habits: Like Father, Like Son, Like Mother, Like Daughter, September 2009

2783 Momi Dahan, Tehila Kogut and Moshe Shalem, Do Economic Policymakers Practice what they Preach? The Case of Pension Decisions, September 2009

2784 Eytan Sheshinski, Uncertain Longevity and Investment in Education, September 2009

2785 Nannette Lindenberg and Frank Westermann, How Strong is the Case for Dollarization in Costa Rica? A Note on the Business Cycle Comovements with the United States, September 2009

2786 Leif Danziger, Noncompliance and the Effects of the Minimum Wage on Hours and Welfare in Competitive Labor Markets, September 2009

2787 Gerlinde Fellner, Rupert Sausgruber and Christian Traxler, Testing Enforcement Strategies in the Field: Legal Threat, Moral Appeal and Social Information, September 2009

2788 Gabriel J. Felbermayr, Mario Larch and Wolfgang Lechthaler, Unemployment in an Interdependent World, September 2009

2789 Sebastian G. Kessing, Federalism and Accountability with Distorted Election Choices, September 2009

2790 Daniel Gros, Global Welfare Implications of Carbon Border Taxes, September 2009

2791 Louis N. Christofides, Michael Hoy and Ling Yang, The Gender Imbalance in Participation in Canadian Universities (1977-2005), September 2009

2792 Jan K. Brueckner and Robert W. Helsley, Sprawl and Blight, September 2009

2793 Vidar Christiansen and Stephen Smith, Externality-correcting Taxes and Regulation, September 2009

2794 John Beirne, Guglielmo Maria Caporale, Marianne Schulze-Ghattas and Nicola Spagnolo, Global and Regional Spillovers in Emerging Stock Markets: A Multivariate GARCH-in-mean Analysis, September 2009 
2795 Rüdiger Pethig and Frieder Kolleß, Asymmetric Capital-Tax Competition, Unemployment and Losses from Capital Market Integration, September 2009

2796 Ngo Van Long, Horst Raff and Frank Stähler, Innovation and Trade with Heterogeneous Firms, September 2009

2797 Margit Osterloh and Bruno S. Frey, Research Governance in Academia: Are there Alternatives to Academic Rankings?, September 2009

2798 Thiess Buettner and Clemens Fuest, The Role of the Corporate Income Tax as an Automatic Stabilizer, September 2009

2799 Annette Alstadsæter, Measuring the Consumption Value of Higher Education, September 2009

2800 Peter Friedrich, Chang Woon Nam and Janno Reiljan, Local Fiscal Equalization in Estonia: Is a Reform Necessary?, September 2009

2801 Evžen Kočenda and Jan Hanousek, State Ownership and Control in the Czech Republic, September 2009

2802 Michael Stimmelmayr, Wage Inequality in Germany: Disentangling Demand and Supply Effects, September 2009

2803 Biswa N. Bhattacharyay, Towards a Macroprudential Surveillance and Remedial Policy Formulation System for Monitoring Financial Crisis, September 2009

2804 Margarita Katsimi, Sarantis Kalyvitis and Thomas Moutos, "Unwarranted" Wage Changes and the Return on Capital, September 2009

2805 Christian Lessmann and Gunther Markwardt, Aid, Growth and Devolution, September 2009

2806 Bas Jacobs and Dirk Schindler, On the Desirability of Taxing Capital Income to Reduce Moral Hazard in Social Insurance, September 2009

2807 Hans Gersbach and Noemi Hummel, Climate Policy and Development, September 2009

2808 David E. Wildasin, Fiscal Competition for Imperfectly-Mobile Labor and Capital: A Comparative Dynamic Analysis, September 2009

2809 Johan Eyckmans and Cathrine Hagem, The European Union's Potential for Strategic Emissions Trading through Minimal Permit Sale Contracts, September 2009

2810 Ruediger Bachmann and Christian Bayer, The Cross-section of Firms over the Business Cycle: New Facts and a DSGE Exploration, October 2009

2811 Slobodan Djajić and Michael S. Michael, Temporary Migration Policies and Welfare of the Host and Source Countries: A Game-Theoretic Approach, October 2009 
2812 Devis Geron, Social Security Incidence under Uncertainty Assessing Italian Reforms, October 2009

2813 Max-Stephan Schulze and Nikolaus Wolf, Economic Nationalism and Economic Integration: The Austro-Hungarian Empire in the Late Nineteenth Century, October 2009

2814 Emilia Simeonova, Out of Sight, Out of Mind? The Impact of Natural Disasters on Pregnancy Outcomes, October 2009

2815 Dan Kovenock and Brian Roberson, Non-Partisan 'Get-Out-the-Vote' Efforts and Policy Outcomes, October 2009

2816 Sascha O. Becker, Erik Hornung and Ludger Woessmann, Catch Me If You Can: Education and Catch-up in the Industrial Revolution, October 2009

2817 Horst Raff and Nicolas Schmitt, Imports, Pass-Through, and the Structure of Retail Markets, October 2009

2818 Paul De Grauwe and Daniel Gros, A New Two-Pillar Strategy for the ECB, October 2009

2819 Guglielmo Maria Caporale, Thouraya Hadj Amor and Christophe Rault, International Financial Integration and Real Exchange Rate Long-Run Dynamics in Emerging Countries: Some Panel Evidence, October 2009

2820 Saša Žiković and Randall K. Filer, Hybrid Historical Simulation VaR and ES: Performance in Developed and Emerging Markets, October 2009

2821 Panu Poutvaara and Andreas Wagener, The Political Economy of Conscription, October 2009

2822 Steinar Holden and Åsa Rosén, Discrimination and Employment Protection, October 2009

2823 David G. Mayes, Banking Crisis Resolution Policy - Lessons from Recent Experience Which elements are needed for robust and efficient crisis resolution?, October 2009

2824 Christoph A. Schaltegger, Frank Somogyi and Jan-Egbert Sturm, Tax Competition and Income Sorting: Evidence from the Zurich Metropolitan Area, October 2009

2825 Natasa Bilkic, Thomas Gries and Margarethe Pilichowski, Stay in School or Start Working? - The Human Capital Investment Decision under Uncertainty and Irreversibility, October 2009

2826 Hartmut Egger and Udo Kreickemeier, Worker-Specific Effects of Globalisation, October 2009

2827 Alexander Fink and Thomas Stratmann, Institutionalized Bailouts and Fiscal Policy: The Consequences of Soft Budget Constraints, October 2009 